Article

\title{
Variability of Non-Polar Secondary Metabolites in the Red Alga Portieria
}

\section{Dioli Ann Payo ${ }^{1, *}$, Joannamel Colo ${ }^{1}$, Hilconida Calumpong ${ }^{2}$ and Olivier de Clerck ${ }^{1, *}$}

1 Phycology Research Group, Ghent University, Krijgslaan 281, S8, 9000 Ghent, Belgium; E-Mail:jm2marine@yahoo.com

2 Institute of Environmental and Marine Sciences, Silliman University, Dumaguete City 6200, Philippines; E-Mail: hpcalumpong@yahoo.com

* Authors to whom correspondence should be addressed; E-Mails: dioli_20@yahoo.com (D.A.P.); olivier.declerck@ugent.be (O.d.C.); Tel.: +32-9-264-8500 (O.d.C.); Fax: +32-9-264-8599 (O.d.C.).

Received: 17 August 2011; in revised form: 1 November 2011 / Accepted: 8 November 2011 / Published: 21 November 2011

\begin{abstract}
Possible sources of variation in non-polar secondary metabolites of Portieria hornemannii, sampled from two distinct regions in the Philippines (Batanes and Visayas), resulting from different life-history stages, presence of cryptic species, and/or spatiotemporal factors, were investigated. PCA analyses demonstrated secondary metabolite variation between, as well as within, five cryptic Batanes species. Intraspecific variation was even more pronounced in the three cryptic Visayas species, which included samples from six sites. Neither species groupings, nor spatial or temporal based patterns, were observed in the PCA analysis, however, intraspecific variation in secondary metabolites was detected between life-history stages. Male gametophytes (102 metabolites detected) were strongly discriminated from the two other stages, whilst female gametophyte (202 metabolites detected) and tetrasporophyte (106 metabolites detected) samples were partially discriminated. These results suggest that life-history driven variations, and possibly other microscale factors, may influence the variation within Portieria species.
\end{abstract}

Keywords: Portieria; secondary metabolite; variation; cryptic species; life-history stages 


\section{Introduction}

Natural products, and in particular secondary metabolites, have been the focus of study in many marine macroalgae. Seaweeds interact with their environment utilizing a rich variety of secondary metabolites [1-4]. These chemical compounds have no explicit role in the internal metabolism of the organisms $[1,5,6]$ but serve as defense mechanisms against grazers, competitors, fouling organisms and pathogens [7-9]. The compounds are localized in specialized cells, have relatively low molecular weights ( $<3000$ Daltons), are structurally diverse, often halogenated, and exist in low abundance (often $<1 \%$ of total carbon) $[1,2,6,10-12]$.

Secondary metabolites have drawn wide attention because of their pharmaceutical potentials, chemotaxonomic and ecological importance [13-16]. Macroalgae produce a wide range of compounds such as terpenes, phenols, fatty acids, lipopeptides, amides, alkaloids, terpenoids, lactones, pyrroles and steroids [9,15,17]. Red seaweeds belonging to the family Rhizophyllidaceae have been found to be especially rich in secondary metabolites, harboring a variety of halogenated monoterpenes. The tropical, Indo-Pacific genus Portieria (synonyms Chondrococcus and Desmia), is a prolific source of these halogenated compounds [11,12,18-24], about 80 of which have been isolated (Table S1). Among the most interesting of these compounds is halomon, a monoterpene with anti-tumor properties, isolated from samples collected in Batanes, Philippines [22,23]. However, the inconsistent availability of this compound from natural populations prevented further drug development.

Previous studies have mainly focused on discovery and pharmaceutical potentials of chemical compounds in $P$. hornemannii. Only a few studies have addressed inter- or intraspecific variation in secondary metabolite composition. Puglisi and Paul [25] tested the carbon/nutrient hypothesis, which postulates that the secondary metabolites produced by a certain alga are dependent on the nutrient availability. They found that variation of ochtodene concentrations in P. hornemannii cannot be attributed to nitrogen and phosphorus availability but suggested instead that light was a contributing factor. Matlock et al. [24] demonstrated strong site-to-site differences, variation within populations, and limited evidence for temporal variation in apakaochtodene levels. Some authors have emphasized the necessity to genotype the organisms in order to better understand the mechanisms that regulate the production of specific natural products [5,26-28]. We found evidence for a large number of cryptic species within Portieria in the Philippines [29], but the effect of intraspecific genetic variation in relation to secondary metabolites has not been tested to date.

This study aims to understand if non-polar secondary metabolites of Portieria plants vary quantitatively or qualitatively between cryptic species and among life stage within species. We employed metabolite fingerprinting and multivariate analyses of chromatograms of extracts of samples collected in the Philippines. The large number of compounds produced by Portieria, the lack of commercial standards and the scarcity of compound identification resources (mass spectral databases) dedicated to marine secondary metabolites makes metabolite fingerprinting the most feasible analytical method to define variation between cryptic species and among life-history stages within species. In contrast to target analysis, metabolite fingerprinting does not separate individual metabolites, but instead compares spectra of whole extracts using multivariate statistics [30]. Metabolite fingerprinting is particularly useful for rapid classification of samples [31]. Our specific aims were to evaluate: (1) if there is variation of non-polar secondary metabolites between the gametophyte and tetrasporophyte life-history 
stages of Portieria, (2) if metabolite variation is due to the presence of phylogenetically distinct cryptic species, and (3) if patterns of variation are observed on a geographical and temporal level.

\section{Results and Discussion}

\subsection{Cryptic Diversity}

Phylogenetic analyses of 152 cox2-3 sequences revealed 12 clades of closely related sequences, preceded by long well-supported branches. Seven lineages include specimens from Batanes and five clades are restricted to the Visayas (Figure 1). These clades will further be regarded as species. Details on cryptic diversity and species delimitation are reported in Payo [29].

Figure 1. Phylogenetic tree reconstructed using Bayesian inference based on the mitochondrial cox2-3 spacer of Portieria specimens collected from Batanes (B) and Visayas (V) Islands in the Philippines. Branch support (posterior probabilities) $\geq 0.5$ are indicated at the branches. The eleven clades represent cryptic lineages, likely equivalent to species. Species B34 and B38 were not included in the chemical analysis.

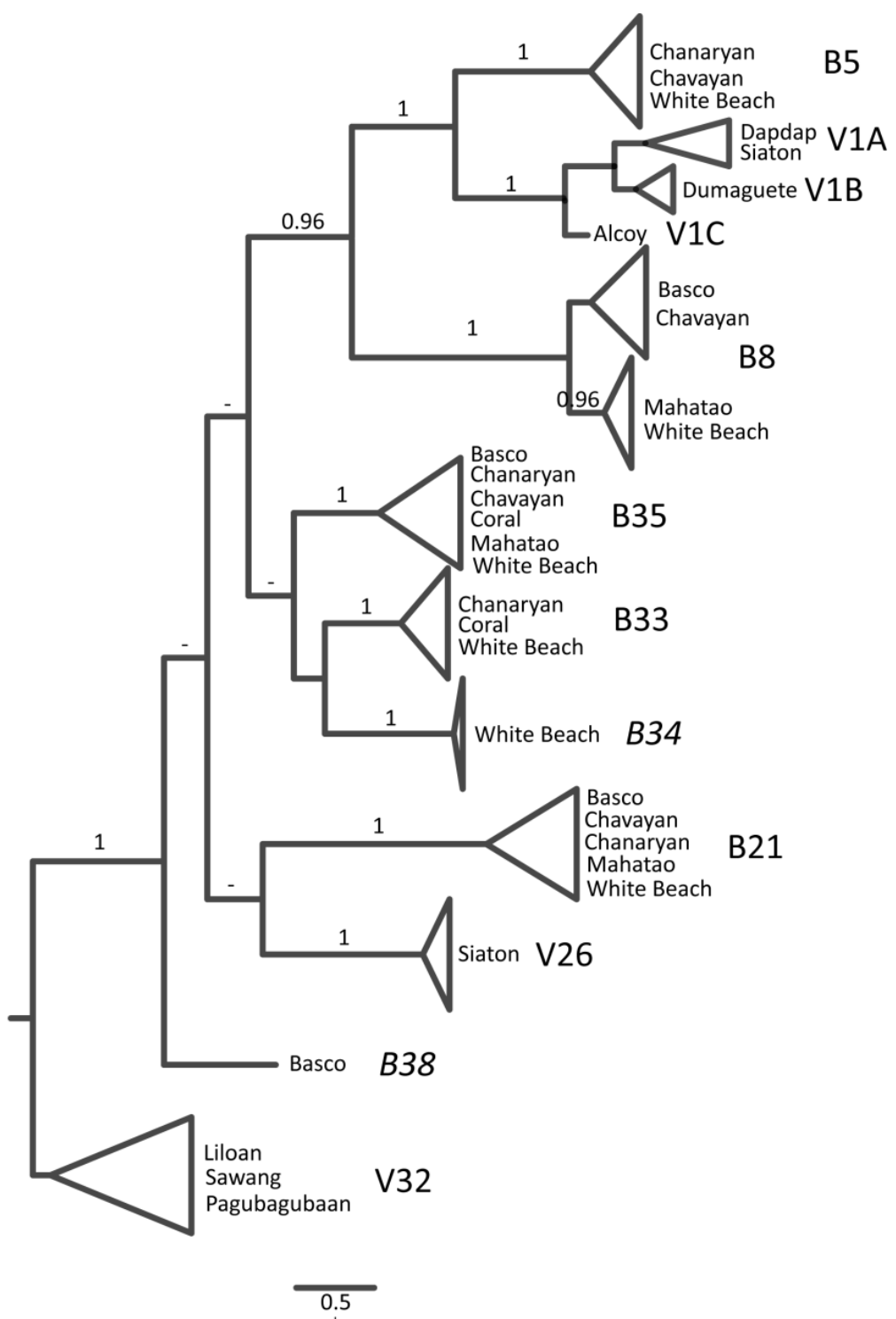




\subsection{Identification of Compounds in Non-Polar Extracts}

Owing to the lack of standard compounds and public repositories of mass spectral data specific to marine metabolites, the identity of the compounds was investigated only by comparing the mass spectra and the Kovats retention indices to those deposited in publicly available databases (MassBase, Pherobase, Lucero Library and the free limited NIST database in the MS Search Program and AMDIS). Identifications were based on a minimum of $80 \%$ similarity of mass fragments. Using a retention index calculator [32], plant volatiles with the nearest Kovats Index (KI) to that of the compounds in the samples were retrieved. The KI used for compound identification is based on a DB5 capillary column similar to the non-polar, low bleed HP-5MS column used for GC/MS in this study. The Lucero KI based identification was verified with the mass spectra and KIs listed in Pherobase. Comparison with mass spectra of compounds found in Portieria in the literature [11,12,33] did not reveal any positive identification. Examination of mass fragments did not show any similarity of components with that of halomon's mass spectral fragments as reported by Egorin et al. [33].

\subsection{Metabolite Fingerprinting}

\subsubsection{Variation Between Life Stages}

Plants used for this study belonged to a single species V1B (Figure 1) and were collected on the same day from a single site in Bantayan, Dumaguete. A total of 202 non-polar compounds were detected from gametophytes and tetrasporophyte samples by GC-MS (Table S2). Using an external standard and the databases, the first peak of each sample (RT $=6.18 \mathrm{~min}$ ) was confirmed as $\beta$-myrcene (Figure 2a). Of the remaining compounds, only $11 \%$ (22) were identified using NIST and MassBase. Based on the NIST and MassBase identifications, five compounds were monoterpenes. Examination of the patterns of parent ions showed ten halogenated compounds containing one $\mathrm{Cl}$ or one Br. Two hundred compounds had a KI ranging 993-1969. Some peaks with succeeding retention times shared the same KI but had a different mass spectra composition. NIST and MassBase did not share the same identification of peaks except for $\beta$-myrcene.

KI for the last two peaks were not computed since it occurred later than the last alkane standard (C20 at $31.226 \mathrm{~min}$ ) that was used for KI calculation. We also explored the potential of the Lucero library and Pherobase to identify compounds that Portieria might have in common with land plants. The Lucero library retrieved the nearest KIs of plant volatiles. Some of these identifications were verified at Pherobase, but mass spectra composition of the unidentified peaks was not similar to the spectra of the compound name retrieved from the database. Furthermore, we also tried to retrieve compounds with a certain KI and examined the corresponding spectra. $\beta$-Myrcene has a KI of 993.543 in this study. Pherobase listed 991 and 994 as KIs for $\beta$-myrcene in a DB5 column. Nine compounds listed in the database have a KI of 993. 
Figure 2. Portion of GC-MS total ion chromatograms of non-polar extracts of Portieria samples: (a) male gametophyte from Bantayan (Dumaguete), V1; (b) White Beach, Batanes, B21; (c) Liloan, V32. $\beta$-myrcene, a precursor of many halogenated monoterpenes, was detected only in the Bantayan specimens. Naphthalene is used as an internal standard.
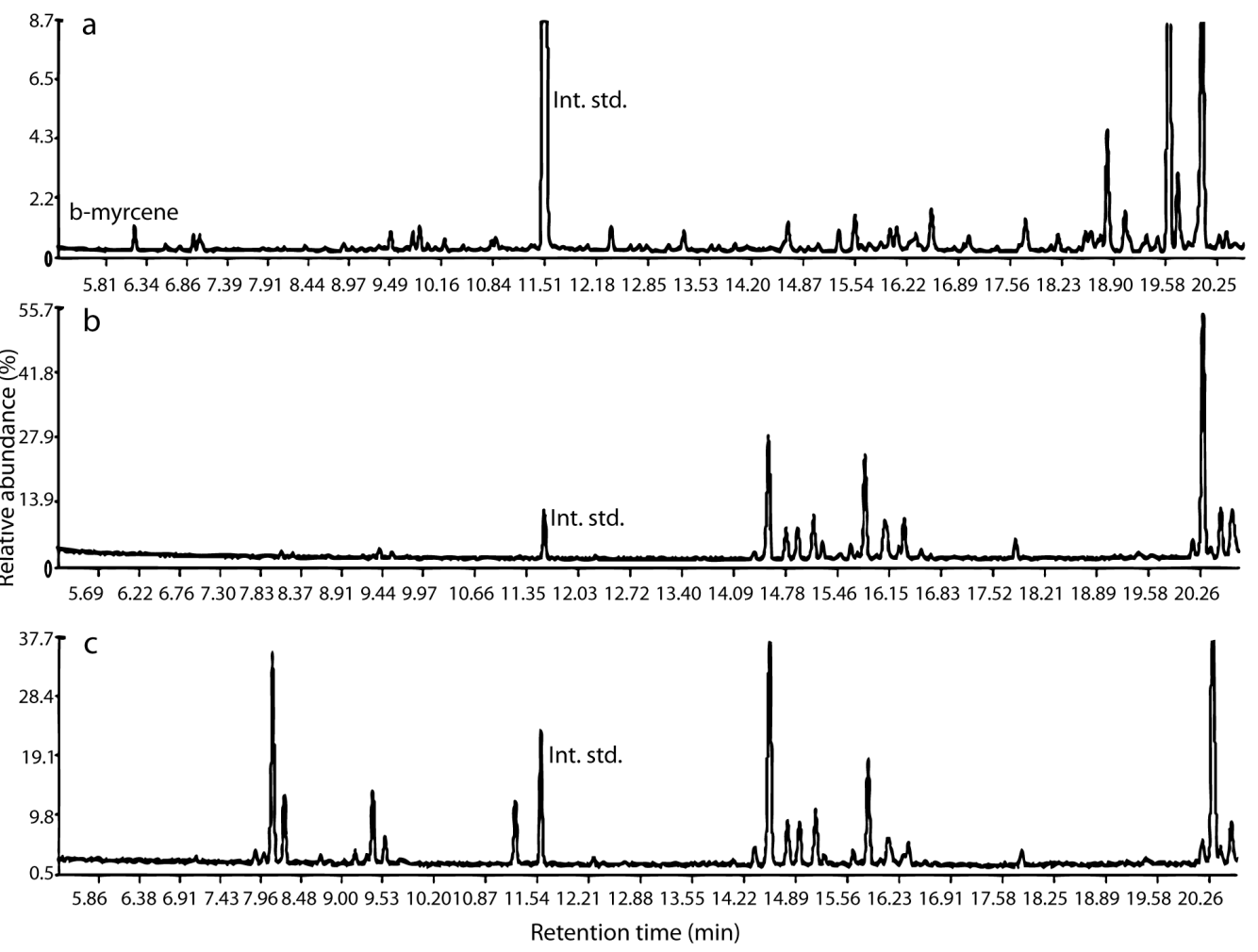

Figure 3. Frequency distribution indicating number of shared and unique non-polar secondary metabolites: (a) within life-history stage of species V1B from Bantayan, female (F), male (M) and tetrasporophyte (T); (b) among sites of species V32 collected in Sawang (SAW), Liloan (LIL) and Pagubagubaan (PAG).

a

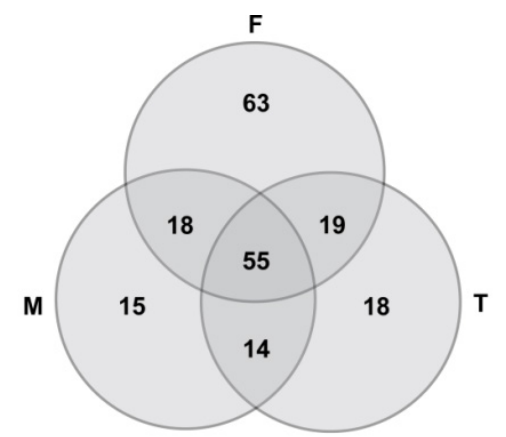

b

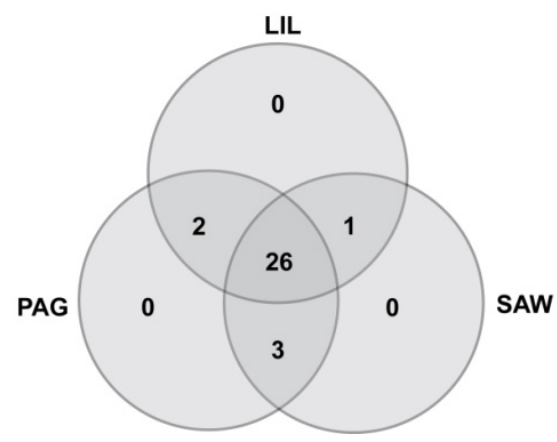


The Lucero library lists KI 993 for $\beta$-myrcene. With the large number of metabolites retrieved, this method of verification proved cumbersome especially since Pherobase currently does not allow automated mass spectral and KI comparison. Of the 202 compounds detected, 155 compounds were present in the female samples, 102 in male plants and 106 in tetrasporophytes (Figure 3a). There were 55 compounds that were shared by all life stages. Sixty-three compounds were found exclusively in female gametophyte extracts, 15 in male gametophyte extracts, and 18 in tetrasporophyte extracts. There were 14 compounds common to male and tetrasporophyte extracts. The male and female gametophyte shared 18 compounds while female and tetrasporophyte shared 19 compounds. A precursor compound of the monoterpenes, myrcene, was detected in all of the life stages but not in all replicates.

Figure 4. Principal component analysis of GC-MS standardized relative abundance datasets which includes the compounds detected in a 67-min run of Portieria extracts. (a) Male gametophyte (M1-2) samples are clearly discriminated occurring at the positive end of the plane while female gametophyte (F2-7) and tetrasporophyte samples (T1-2) are only partially discriminated by Factor 1; (b) Batanes dataset includes five cryptic species. The clustering of B35 replicates and the scattered pattern of B5 suggest variation in component compounds exists between species but at the same time suggested that variation within species can occur.
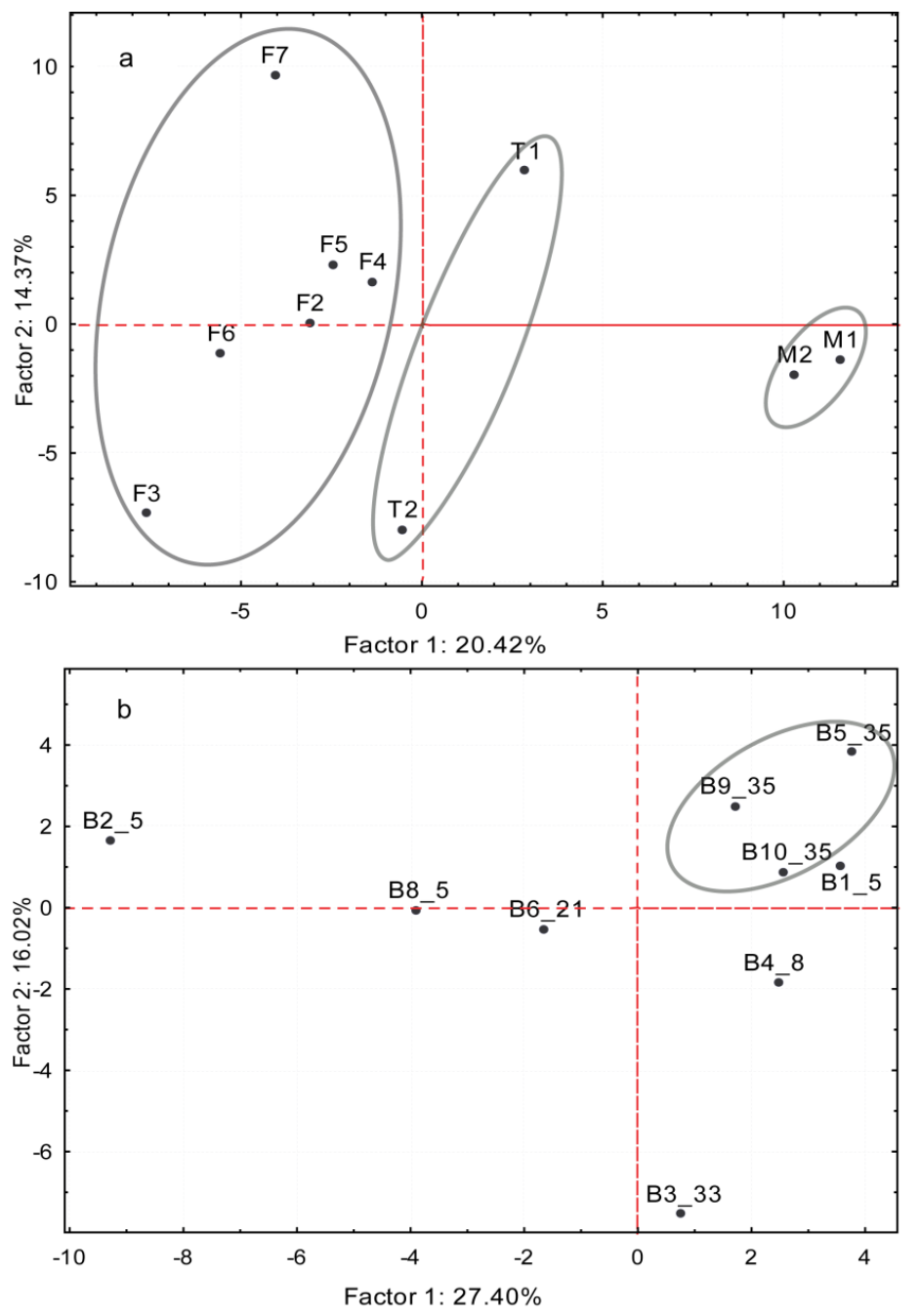
We applied a principal component analysis (PCA) on the standardized relative abundances to determine if metabolites differ among life stages (Figure 4a). The matrix contained 202 compounds (active variables) and ten samples (active cases: six female gametophytes, two male gametophytes, and two tetrasporophytes). All samples were collected on the same day from a single site, and belong to a single species. Figure $4 \mathrm{a}$ shows the projection of the cases on the factor plane. Factor 1 and factor 2 accounts for $20.42 \%$ and $14.37 \%$ of the variation, respectively. Factor 1 clearly discriminated the male gametophytes from the others, whilst the female gametophytes and tetrasporophytes, although separated, were more closely aligned. Factor 2 does not discriminate between life stages but points towards additional variation within life stages.

\subsubsection{Variation Between Cryptic Species}

A total of 67 compounds were detected from nine samples (three technical replicates) by GC-MS (Table S3). These samples belonged to the five species B8, B5, B21, B33 and B35, as determined by DNA sequence analysis. A sample consists of pooled extract of eight individuals belonging to one species as verified by DNA analysis. $\beta$-Myrcene was not detected in any of the samples (Figure $2 b$ ). Unfortunately the three databases used (NIST, MassBase, Lucero library) did not give identical identifications of compounds. NIST identified four compounds appearing at different times as 2,2-dimethyl-3-hexanone. Comparison of mass spectra with MassBase resulted in the retrieval of straight and branched alkanes and alkenes. Compounds with retention times from 8.11 to $30.69 \mathrm{~min}$ had retention indices from 1065 to 1965 . No KIs were computed for the rest of the compounds. Comparison of computed KIs with those in the Lucero library indicated compounds from these samples contained monoterpenes, sesquiterpenes, esters, fatty acids and alcohols. NIST, MassBase and the Lucero databases did not share the same identification of compounds. Visual examination of parent ions showed only two compounds to be halogenated containing either one $\mathrm{Cl}$ or one $\mathrm{Br}$.

Table 1. Frequency of compounds that are unique to or common to several species of Portieria found in Batanes. Values in parenthesis indicate total number of compounds found in a species, while 1 indicates presence and 0 absence of a compound.

\begin{tabular}{cccccc}
\hline B21 (49) & B33 (51) & B35 (60) & B8 (57) & B5 (57) & Frequency (67) \\
\hline 0 & 0 & 0 & 1 & 0 & 1 \\
0 & 0 & 1 & 1 & 0 & 3 \\
0 & 0 & 1 & 1 & 1 & 3 \\
0 & 1 & 0 & 0 & 0 & 1 \\
0 & 1 & 0 & 1 & 0 & 2 \\
0 & 1 & 1 & 1 & 0 & 1 \\
0 & 1 & 1 & 1 & 1 & 7 \\
1 & 0 & 1 & 0 & 1 & 3 \\
1 & 0 & 1 & 1 & 0 & 2 \\
1 & 0 & 1 & 1 & 1 & 4 \\
1 & 1 & 0 & 0 & 1 & 2 \\
1 & 1 & 0 & 1 & 1 & 1 \\
1 & 1 & 1 & 0 & 1 & 4 \\
1 & 1 & 1 & 1 & 1 & 33 \\
\hline
\end{tabular}


The number of compounds detected varied between the five species (Table 1) and among biological replicates. Species B35 had the highest number of compounds detected (60/67), species B33 contained 51/67 compounds detected, species B8 and B5 both had 57/67 compounds detected and species B21 had the least number of compounds (49/67). There were 21 compounds that were detected in all nine samples, while 33 compounds were present in all five species.

To detect distinct groupings, we conducted a PCA based on the standardized relative abundances of the nine samples using the 67 compounds as variables (Figure 4b). The first principal axis accounted for $27.4 \%$ of the variance while the second $16.0 \%$. Plotted scores from the PCA did not show distinct interspecific clusters. The largest variation was displayed by specimens belonging to species B5.

\subsubsection{Spatial and Temporal Variation}

Six sites in the Visayas (Sawang, Pagubagubaan, Dapdap, Siaton, Liloan and Bantayan (Dumaguete); $n=44$ ) were sampled from 2007 to 2009 and investigated using Spectconnect to determine if seasonality or geography explained the variation in secondary metabolites. A total of 33 compounds were detected from these samples (Table S4), however, $\beta$-myrcene was not detected (Figure $2 \mathrm{c}$ ). As in previous datasets, the three databases (NIST, MassBase, Lucero library) used did not give identical identifications of compounds. Comparison of mass spectra with MassBase resulted in the retrieval of eleven compounds, most likely straight and branched alkanes and alkenes. Many of the peaks detected eluted later than the standard, icosane (C20), hence were not included. Comparison of computed RIs with those in Lucero library retrieved the following compound classes: monoterpenes, sesquiterpenes, esters and fatty acids. NIST library identified two compounds, 3-hexanone, 2,2-dimethyl- and disilane. No halogenated compounds were detected.

Figure 5. Principal component analysis of GC-MS standardized relative abundance datasets for detecting possible spatial and temporal patterns in: (a) the Visayas species; (b) the Visayas samples belonging to species V32. Letters indicate sampling site (DAP: Dapdap; PAG: Pagubagubaan; SAW: Sawang; SIA: Siaton) and numbers indicate month and year of sampling.

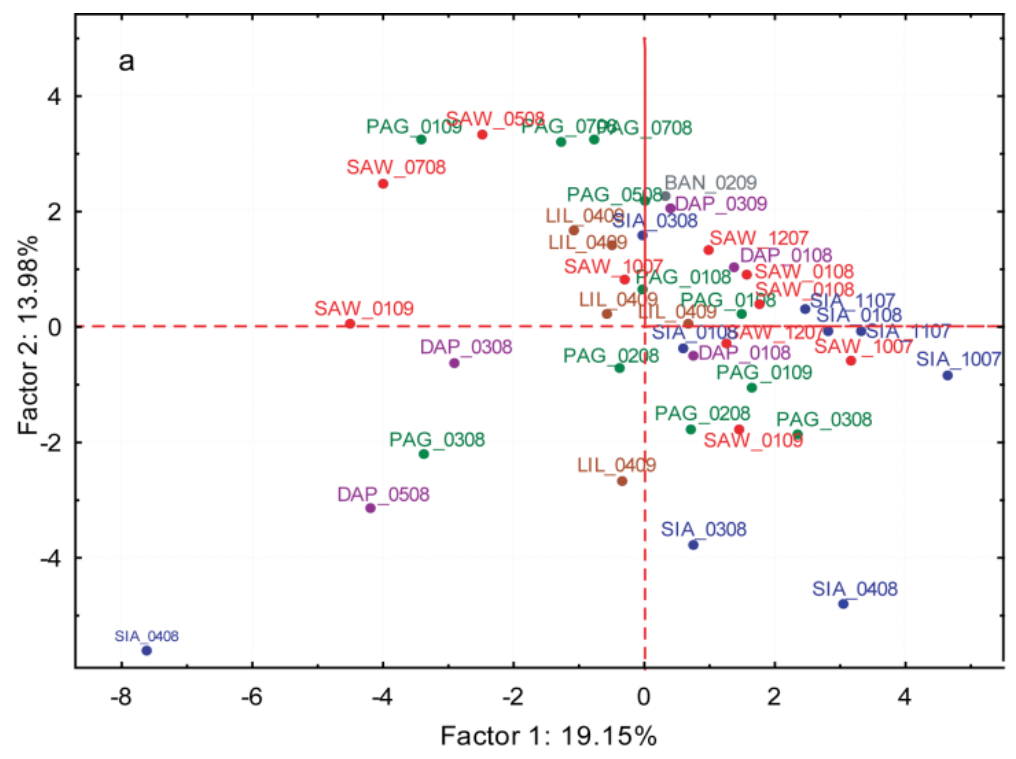


Figure 5. Cont.

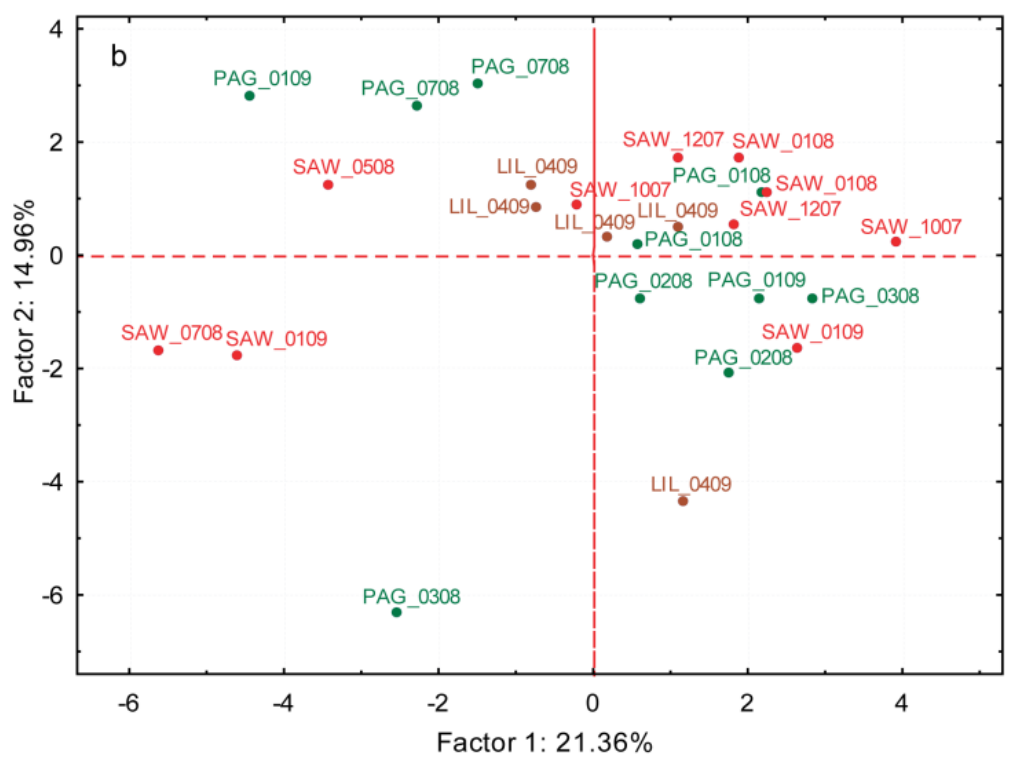

PCA was conducted using the standardized relative abundance file generated by Spectconnect ( $n=44$ ) using the 33 compounds as variables (Figure 5a). The first and second PCs accounted for $17.87 \%$ and $17.78 \%$ of the variance, respectively. No clear groupings could be deduced based on species, sampling period, or sampling site. Most of the samples clumped except for one Siaton and two Bantayan samples, which were clearly separated from the rest. A PCA excluding these three samples slightly spread the rest of the samples but likewise did not show any recognizable clusters (Figure 5a). A separate PCA analysis was conducted on samples belonging to the same species, V32, from Sawang, Pagubagubaan, and Liloan (Figure 5b). The first and second PCs accounted for $21.36 \%$ and $14.96 \%$ of the variance, respectively. Again, no clusters based on site or period of collection were detected.

\subsection{Patterns of Secondary Metabolite Distribution}

Distribution of secondary metabolites in marine macroalgae exhibit macroscale and microscale patterns [34]. Macroscale patterns include global patterns within or across algal taxa, patterns within a specific habitat, and patterns correlated with biotic and abiotic factors. Microscale patterns are related to molecular and biochemical processes within an algal thallus, the spatial distribution of compounds within an algal thallus and temporal responses (short- and long-term responses). In Portieria neither macro- nor microscale patterns of secondary metabolite variation have been fully explored.

Although three decades of studies have been dedicated to the isolation of new compounds only two have investigated the variation of these, specifically ochtodene and apakaochtodene A and B [24,25]. However, a possible drawback related to these studies is the fact that individual compounds are not mutually independent but are linked via biological pathways as is the case for $\beta$-myrcene, which is the likely precursor of many monoterpenes [35], and whose presence influences the presence or absence of other halogenated monoterpene components. Hence in order to understand general or specific metabolite patterns, knowledge of the presence and absence of progenitor compounds is essential. The present study has successfully described the variation of the non-polar secondary metabolites of Portieria on a macroscale level using metabolite fingerprinting. 
Reports on intraspecific variation of secondary metabolites in macroalgae have been based on variations within individuals, between individuals of a population and among geographically isolated populations [36,37]. Our results suggest substantial intraspecific variation among the life-history stages of Portieria. Male gametophytes form a clearly distinct group, while a partial discrimination was detected between female gametophytes and tetrasporophytes (Figure 4a). Furthermore, our results show that female gametophytes are chemically richer in terms of the number of secondary metabolites (Figure 3a), possibly providing protection to the carposporophyte from grazers. Many of the compounds detected appear to occur exclusively to a certain life-history stage while a relatively small group of compounds is shared among life-history stages. Similarly, male gametophytes of Asparagopsis armata were found to have lower concentration of the secondary metabolite bromoform compared to female gametophytes [37]. It has also been observed that the carposporophyte phase of $A$. armata was the least consumed life-history phase by the seahare, Aplysia parvula [37]. Likewise, in the brown alga Dictyota menstrualis, female gametophytes were found to produce more diterpenes compared to the other life-history stages [38].

Comparative analyses of the five cryptic species from Batanes (B5, B21, B33, B35, and B8) showed variation between, as well as within species (Figure 4b). Intraspecific variation is even more pronounced in the Visayas dataset (Figure 5). Neither species specific nor spatio-temporal patterns were evident.

In addition, a separate PCA including only specimens of species V32 (Figure 3b) did not elucidate patterns based on collection site or period. The results suggest that life history related variations combined with microscale factors have a large influence on the variation within Portieria species. Pelletreau and Targett [34] pointed out that the existence of inducible and activated defenses complicates the search for universal patterns of secondary metabolites and continues to highlight the importance of localized phenomena. We conducted a preliminary grazing experiment in outdoor flow-through aquaria to assess the influence of the herbivore (Aplysia) on the production of metabolites in Portieria. However, these efforts were beset by two factors: death of plants due to high water temperature and continuous development of microscopic Aplysia larvae on field collected plants undergoing acclimatization. Future grazing experiments will attempt to eliminate these factors. In addition more extensive sampling should confirm the patterns observed during the present study.

Finally, there was difficulty in achieving unequivocal identification of compounds in this study unveiling the need for mass spectral and KI databases dedicated solely to marine secondary metabolites. Such repositories will assist in the identification of previously reported compounds for investigations mainly focused on rapid detection and understanding of chemical patterns in marine organisms. In doing so, future studies will not just be focused in isolating and naming novel compounds as had been the trend in Portieria but will also seek to answer questions of biological or ecological relevance. Furthermore, the presence of cryptic species in Portieria highlights the need to genotype organisms ensuring that correct species identification is correlated with metabolite fingerprint, enabling more targeted approaches in future studies. 


\section{Experimental Section}

\subsection{Collection and Storage}

Field samplings were performed at different periods from several sites in the Philippines (Figure S1). Plants were collected by snorkeling and SCUBA, diving depths ranging from 1-20 m. For secondary metabolite characterization of the different life-history stages of Portieria, plants were collected randomly from Bantayan near Dumaguete (Figure S1c) on December 29, 2009. To allow both chemical characterization and life-history stage verification plants were blotted dry and stored over silica.

Plants for secondary metabolites analysis between species were collected from four sites in Batanes (Basco, White Beach, Coral, and in Chavayan) (Figure S1a,b) on April 23-26, 2009. Plants were preserved in $95 \%$ ethanol in the field and stored at $-23{ }^{\circ} \mathrm{C}$ afterwards. Sampling for seasonal and spatial comparison of secondary metabolites were conducted from six sites in the Central Visayas (Dapdap, Siquijor, Siquijor; Pagubagubaan, San Juan, Siquijor; Sawang, San Juan Siquijor; Bantayan, Dumaguete, Negros Oriental; Siaton, Negros Oriental; Liloan, Santander, Cebu (Figure S1a,c) from 2007 to 2009. For the first four sites, plants were collected on a monthly basis when present and when abundant enough to afford a good amount for extraction. For sites close to the Silliman Marine Laboratory, plants were immediately packed and stored at $-23{ }^{\circ} \mathrm{C}$ upon arrival. When immediate freezing was not possible, plants were preserved in $95 \%$ ethanol in the field and stored at $-23{ }^{\circ} \mathrm{C}$. Frozen plants were rinsed in freshwater or in ethanol and blotted dry.

As Portieria cannot be distinguished morphologically, species identification was based on DNA sequence data (see below). For DNA characterization, thallus clippings were collected from specimens and stored in silica while in the field.

\subsection{Extraction}

\subsubsection{Life-History Stages Comparison}

Portieria has a tri-phasic isomorphic life history which includes free-living haploid male and female gametophytes, a diploid carposporophyte attached to and dependent on the female gametophyte, and a free-living diploid tetrasporophyte. Silica-dried specimens were examined under the microscope and segregated into different life-history stages (male gametophytes, female gametophytes, and tetrasporophytes). Biological replicates, each about 1 gram dry weight, were prepared for every life-history stage. Tissues were ground using mortar and pestle, dissolved in $6 \mathrm{~mL}$ dichloromethane (DCM) containing $50 \mu \mathrm{g} \cdot \mathrm{mL}^{-1}$ naphthalene, and vortexed for a few seconds. The DCM extracts were allowed to stand at room temperature for $24 \mathrm{~h}$ in screw-cap tubes. The extracts were decanted and transferred to air tight screw-cap tubes and stored at $-23{ }^{\circ} \mathrm{C}$. The tissues were steeped in DCM for another $24 \mathrm{~h}$. First and second extracts of a sample were pooled and filtered using Whatman GF/C. The combined extracts were loaded onto pre-conditioned SPE tubes containing $10 \mathrm{~g}$ of silica (Silicycle SiliaFlash $^{\circledR}$ G60, 60-200 $\mu \mathrm{m}, 60 \AA$ ). Non-polar compounds were eluted using $12 \mathrm{~mL}$ hexane. The eluate was concentrated to $0.5 \mathrm{~mL}$ under $\mathrm{N}_{2}$ gas. Three $100 \mu \mathrm{L}$ replicates were taken from this stock and used as technical replicates in the GC-MS analysis. 


\subsubsection{Species Comparison}

The samples were extracted individually. Tissue was ground using a mortar and pestle and extracted twice in $6 \mathrm{~mL}$ DCM overnight. Extracts were pooled, loaded onto $2 \mathrm{~g}$ silica and eluted using $6 \mathrm{~mL}$ of hexane. Eluates of eight samples belonging to the same species, approximately weighing 10-26 g, were pooled and evaporated down to $100 \mu \mathrm{L}$. To assess consistency in the GC-MS analyses, three technical replicates were prepared for each sample.

HPLC solvents for extraction and chromatography (DCM and $n$-hexane) were sourced from Mallinckrodt or HiperSolv Chromanorm). Naphthalene (Fisher) and $\beta$-myrcene (Sigma) were used as internal and external standards, respectively.

\subsubsection{Seasonal and Spatial Comparison}

For seasonal analysis, plant material was ground using mortar and pestle. Twenty grams of ground material was extracted in $20 \mathrm{~mL}$ DCM for $24 \mathrm{~h}$ at room temperature. The material was extracted a second time in $20 \mathrm{~mL}$ DCM and the extracts were pooled. To measure the amount of green oil that was generated, one of the two pooled extracts was evaporated to dryness using nitrogen. The oil was weighed and redissolved in $20 \mathrm{~mL}$ DCM. The other extract was evaporated down to $20 \mathrm{~mL}$. Both extracts were loaded in SPE columns containing $10 \mathrm{~g}$ of silica (Silicycle SiliaFlash ${ }^{\circledR}$ G60, 60-200 $\mu \mathrm{m}$, $60 \AA$ ). Non-polar compounds were eluted from the column with $20 \mathrm{~mL}$ hexane and again reduced to $100 \mu \mathrm{L}$. A separate aliquot of ground plant tissue was used to determine dry mass.

\subsection{Phylogenetic Analysis}

Assignment of the sampled specimens to cryptic species was based on phylogenetic analysis of the mitochondrial cox2-3 spacer region. The phylogeny includes specimens collected from five sites (Basco, Chanaryan, Coral, Mahatao, Chavayan) in Batanes and six sites (Dapdap, Siquijor; Sawang, San Juan, Siquijor; Pagubagubaan, San Juan, Siquijor; Malo, Siaton; Bantayan, Dumaguete; Liloan, Santander) in the Visayas, Philippines. Species delineation follows the rational outlined in Payo et al. [29]. DNA extraction, PCR amplification, sequencing and sequence alignment were performed as described in Payo et al. [29].The alignment of 152 Portieria sequences was 345 bp long. Bayesian inference (BI) of phylogeny was performed using MrBayes v3.1.2 [39] under a GTR $+\mathrm{I}+\Gamma$ model as determined by jModelTest [40]. BI analyses consisted of two parallel runs of three incrementally heated chains and one cold chain each, and 3 million generations with sampling every 1000 generations. A burnin value of 750 was determined using TRACER V1.4 [41].

\subsection{Metabolite Analysis, Data Processing and Multivariate Analysis}

\subsubsection{GC-MS Analysis}

GC-MS analyses of the non-polar eluates were performed using an Agilent 6890 gas chromatograph and Agilent 6973 mass selective detector. Sample injection volume was $1 \mu \mathrm{L}$. Split injection with a split ratio of 20:1 was used. The carrier gas was helium with a total flow rate of $72.7 \mathrm{~mL} \cdot \mathrm{min}^{-1}$ and 26.20 psi column head pressure. Compounds were separated using a $30 \mathrm{~m} \times 0.25 \mathrm{~mm}$ HP-5 MS 
non-polar capillary column (Hewlett-Packard, 5\% phenyl methyl siloxane, $0.25 \mu \mathrm{m}$ thickness) for a run time of $67 \mathrm{~min}$. under the following oven temperature program: $50{ }^{\circ} \mathrm{C}$ initial held for $2 \mathrm{~min}$, then increased at a rate of $5{ }^{\circ} \mathrm{C} \cdot \mathrm{min}^{-1}$ to $300{ }^{\circ} \mathrm{C}$, held for $15 \mathrm{~min}$. The spectrometers were run in electron-impact mode with ionization energy of $70 \mathrm{eV}$ and an ion source temperature ranging $230-250{ }^{\circ} \mathrm{C}$. The scan range was set to detect masses 50-500 amu.

\subsubsection{GC-MS Data Processing}

The software AMDIS [42] was used for peak identification and deconvolution of the chromatogram. This method calculates and retrieves pure (background-free) mass spectra from raw GC-MS data files based from the parameters indicated by the user. The following parameters were used for all of the analyses: medium shape requirement, medium sensitivity, and medium resolution. The ELU files generated from AMDIS were submitted for analysis using Spectconnect [43] to generate matrices of component peaks (relative abundance, retention time, integrated signal and base peak).

\subsubsection{Compound Identification}

In the absence of pure standards of compounds previously isolated from Portieria (except for $\beta$-myrcene), we used KI's, freely available mass spectral databases to determine identity of component peaks, and literature. We computed the Kovat's or retention index of each peak using the retention times of alkane standards C8-C20 and the Retention Index Calculator [32]. The retention index is derived from the interpolation (usually logarithmic), relating the adjusted retention volume (time) of the sample component to the adjusted retention volumes (times) of two standards eluted before and after the peak of a sample component (IUPAC definition). The calculated KI was automatically compared to the KI's of compounds stored in the built-in library of the calculator. Mass spectra of component peaks were compared to compounds retrieved from MassBank [44], Pherobase [45] and the limited version of the NIST library in the MS Search Program and AMDIS. Mass spectra of components were inspected for similarity with those of the characteristic mass signals of components published in $[11,12,33]$.

\subsubsection{Data Standardization, Metabolite Fingerprinting and Multivariate Analyses}

Relative abundance matrices generated from the Spectconnect analyses were used for statistical analyses. A matrix contains relative abundance values of all detected components across all samples included in the analysis. The data were standardized by obtaining a ratio between the relative abundance of a component per replicate (or sample) and the total of all components per replicate (or sample). The ratios obtained among the technical replicates were subsequently averaged. Principal component analysis was performed using Statistica 7.0 (StatSoft Inc., Tulsa, OK, USA) on each dataset to detect any pattern or groupings based from the variables which are the component compounds. 


\section{Conclusions}

Portieria species in the Philippines are a rich source of secondary metabolites. This diversity in secondary metabolites amounts to at least 302 various compounds. The majority of which are exotic, remain undescribed and therefore are not available in natural product databases. Our study demonstrates that metabolic fingerprinting presents a practical approach to disclose intra- and interspecific patterns of secondary metabolites. Variation in secondary metabolites occurs between, as well as within, Portieria species. Preliminary results, based on a relatively small sample size, demonstrate that extensive intraspecific variation in secondary metabolites occurs between life-history stages. Female gametophytes (202 compounds) are chemically richer compared to that of the males (102) and tetrasporophytes (106). No spatio-temporal patterns were evident among the datasets. These results suggest that life-history driven variations and possibly other microscale factors may have an important influence on the variation of secondary metabolites within Portieria species. More exhaustive sampling is needed to confirm the life-stage specific metabolic fingerprints. In addition, to determine whether the intraspecific variation of the analyzed part of non-polar metabolome remains lower than the interspecific variation, it will be necessary to expand the taxon sampling across different cryptic species.

\section{Acknowledgments}

The authors are grateful to Abner Bucol, Zacharias Generoso and Jacinta Lucañas of IEMS-Silliman University for field assistance, Batanes MENRO Francis Domingo for field and dive assistance, Frederik Lynen (Department of Organic Chemistry, UGent) and co-workers for the helpful suggestions and access to GC-MS and HPLC instruments during the exploratory period of the chemical analysis. Special gratitude goes to Elie Verleyen and Wim Vyverman (Protistology and Aquatic Ecology, UGent) for allowing us to use the GC-MS equipment (FWO Grant 1516906N) and Renaat Dasseville for the valuable technical assistance. Funding for this research was provided by the Flemish Interuniversity Council (VLIR) as part of the PhD Grant to D.A. Payo.

\section{Supplementary}

Table S1. List of compounds isolated from Portieria (syn. Desmia and Chondrococcus) hornemannii, based on previous studies.

\begin{tabular}{|c|c|c|c|c|c|}
\hline Reference & Cpd \# & Name & Mol. Formula & Description & Specimen Source \\
\hline \multirow[t]{7}{*}[18]{} & 1 & Myrcene & $\mathrm{C}_{10} \mathrm{H}_{16}$ & $\begin{array}{l}\text { acyclic } \\
\text { halogenated } \\
\text { monoterpene }\end{array}$ & Amami Is., Japan \\
\hline & 2 & 7-chloro-myrcene & $\mathrm{C}_{10} \mathrm{H}_{15} \mathrm{Cl}$ & " & " \\
\hline & 3 & 7-bromo-myrcene & $\mathrm{C}_{10} \mathrm{H}_{15} \mathrm{Br}$ & " & $"$ \\
\hline & 4 & (Z)-10-bromo-myrcene & $\mathrm{C}_{10} \mathrm{H}_{15} \mathrm{Br}$ & " & " \\
\hline & 5 & (E)-10-bromo-myrcene & $\mathrm{C}_{10} \mathrm{H}_{15} \mathrm{Br}$ & $"$ & $"$ \\
\hline & 6 & $\begin{array}{l}\text { (Z)-10-bromo-7-chloro- } \\
\text { myrcene }\end{array}$ & $\mathrm{C}_{10} \mathrm{H}_{14} \mathrm{BrCl}$ & " & " \\
\hline & 7 & $\begin{array}{l}\text { (E)-10-bromo-7- } \\
\text { chloro-myrcene }\end{array}$ & $\mathrm{C}_{10} \mathrm{H}_{14} \mathrm{BrCl}$ & " & $"$ \\
\hline
\end{tabular}


Table S1. Cont.

\begin{tabular}{|c|c|c|c|c|c|}
\hline & 8 & $\begin{array}{l}\text { 3-chloro-7, }(Z)-10 \text { - } \\
\text { dibromo-myrcene }\end{array}$ & $\mathrm{C}_{10} \mathrm{H}_{13} \mathrm{Br}_{2} \mathrm{Cl}$ & " & " \\
\hline & 9 & $\begin{array}{l}\text { (Z)-10-chloro-3,7- } \\
\text { dibromo-myrcene }\end{array}$ & $\mathrm{C}_{10} \mathrm{H}_{13} \mathrm{Br}_{2} \mathrm{Cl}$ & " & $"$ \\
\hline & 10 & $\begin{array}{l}\text { 3-bromo-7-chloro- } \\
\text { myrcene }\end{array}$ & $\mathrm{C}_{10} \mathrm{H}_{14} \mathrm{BrCl}$ & $"$ & $"$ \\
\hline & 11 & $\begin{array}{l}\text { 7-bromo-10-chloro- } \\
\text { myrcene }\end{array}$ & $\mathrm{C}_{10} \mathrm{H}_{14} \mathrm{BrCl}$ & " & $"$ \\
\hline & 12 & - & $\mathrm{C}_{10} \mathrm{H}_{15} \mathrm{Br}$ & $\begin{array}{l}\text { cyclic halogenated } \\
\text { monoterpene }\end{array}$ & $"$ \\
\hline \multirow[t]{2}{*}{ [19] } & 1 & chondrocole A & $\mathrm{C}_{10} \mathrm{H}_{14} \mathrm{BrClO}$ & $"$ & Hawaii \\
\hline & 2 & chondrocole B & $\mathrm{C}_{10} \mathrm{H}_{14} \mathrm{BrClO}$ & " & Hawaii \\
\hline \multirow[t]{10}{*}[46]{} & 3 & - & $\mathrm{C}_{10} \mathrm{H}_{15} \mathrm{Cl}_{3} \mathrm{Br}_{2}$ & $\begin{array}{l}\text { acyclic } \\
\text { halogenated } \\
\text { monoterpene }\end{array}$ & $\begin{array}{l}\text { Black Point, } \\
\text { Oahu, Hawaii }\end{array}$ \\
\hline & 4 & - & $\mathrm{C}_{10} \mathrm{H}_{16} \mathrm{Cl}_{3} \mathrm{Br}$ & $"$ & $"$ \\
\hline & 5 & - & $\mathrm{C}_{10} \mathrm{H}_{15} \mathrm{Cl}_{2} \mathrm{Br}$ & $"$ & " \\
\hline & 6 & - & $\mathrm{C}_{10} \mathrm{H}_{16} \mathrm{Cl}_{2} \mathrm{Br}_{2}$ & $"$ & $\begin{array}{l}\text { Halona Blowhole } \\
\text { Is, Oahu, Hawaii }\end{array}$ \\
\hline & 10 & - & $\mathrm{C}_{10} \mathrm{H}_{16} \mathrm{Cl}_{2} \mathrm{Br}_{2}$ & $\begin{array}{l}\text { acyclic } \\
\text { halogenated } \\
\text { monoterpene }\end{array}$ & " \\
\hline & 11 & $\begin{array}{l}\text { 6-bromo-2- } \\
\text { chloromyrcene }\end{array}$ & $\mathrm{C}_{10} \mathrm{H}_{15} \mathrm{ClBr}$ & $"$ & $\begin{array}{l}\text { Black Point, } \\
\text { Oahu, Hawaii }\end{array}$ \\
\hline & 12 & chondrocole c & $\mathrm{C}_{10} \mathrm{H}_{14} \mathrm{Br}_{2} \mathrm{O}$ & $\begin{array}{l}\text { cyclic halogenated } \\
\text { monoterpene }\end{array}$ & $"$ \\
\hline & 13 & - & $\mathrm{C}_{10} \mathrm{H}_{15} \mathrm{Cl}_{3} \mathrm{Br}_{2}$ & $\begin{array}{l}\text { acyclic } \\
\text { halogenated } \\
\text { monoterpene }\end{array}$ & Hawaii \\
\hline & 14 & $\begin{array}{l}\text { Z-3-bromomethylene- } \\
\text { 7-methyl-1,6-octadiene }\end{array}$ & $\mathrm{C}_{10} \mathrm{H}_{16} \mathrm{ClBr}_{2}$ & $"$ & $\begin{array}{l}\text { Halona Blowhole } \\
\text { Is., Oahu, Hawaii }\end{array}$ \\
\hline & 15 & - & $\mathrm{C}_{10} \mathrm{H}_{14} \mathrm{Br}_{2} \mathrm{Cl}_{2}$ & $\begin{array}{l}\text { cyclic halogenated } \\
\text { monoterpene }\end{array}$ & " \\
\hline \multirow[t]{7}{*}[47]{} & 1 & myrcene & $\mathrm{C}_{10} \mathrm{H}_{16}$ & $\begin{array}{l}\text { acyclic } \\
\text { halogenated } \\
\text { monoterpene }\end{array}$ & $\begin{array}{l}\text { Kada Coast, } \\
\text { Wakayama Pref., } \\
\text { Japan }\end{array}$ \\
\hline & 2 & 7-chloro-myrcene & $\mathrm{C}_{10} \mathrm{H}_{15} \mathrm{Cl}$ & " & " \\
\hline & 3 & 7-bromo-myrcene & $\mathrm{C}_{10} \mathrm{H}_{15} \mathrm{Br}$ & $"$ & $"$ \\
\hline & 4 & 3,7-dichloro-myrcene & $\mathrm{C}_{10} \mathrm{H}_{14} \mathrm{C}_{12}$ & $"$ & $"$ \\
\hline & 5 & $\begin{array}{l}\text { (Z)-10-bromo-3- } \\
\text { methoxy- } \alpha \text {-myrcene }\end{array}$ & $\mathrm{C}_{11} \mathrm{H}_{17} \mathrm{OBr}$ & $"$ & $"$ \\
\hline & 6 & $\begin{array}{l}(E)-10 \text {-bromo-3- } \\
\text { methoxy- } \alpha \text {-myrcene }\end{array}$ & $\mathrm{C}_{11} \mathrm{H}_{17} \mathrm{OBr}$ & $"$ & $"$ \\
\hline & 7 & $\begin{array}{l}\text { 3-bromo-7-chloro- } \\
\text { myrcene }\end{array}$ & $\mathrm{C}_{10} \mathrm{H}_{14} \mathrm{BrCl}$ & $"$ & $"$ \\
\hline
\end{tabular}


Table S1. Cont.

\begin{tabular}{|c|c|c|c|c|c|}
\hline & 8 & $\begin{array}{l}\text { (Z)-10-bromo-1- } \\
\text { methoxy-myrcene }\end{array}$ & $\mathrm{C}_{11} \mathrm{H}_{17} \mathrm{OBr}$ & " & " \\
\hline & 9 & $\begin{array}{l}\text { (E)-10-bromo-1- } \\
\text { methoxy-myrcene }\end{array}$ & $\mathrm{C}_{11} \mathrm{H}_{17} \mathrm{OBr}$ & " & " \\
\hline [48] & & $\begin{array}{l}\text { (-)-3-bromomethyl-3- } \\
\text { chloro-7-methyl-1,6- } \\
\text { octadiene }\end{array}$ & $\mathrm{C}_{10} \mathrm{H}_{16} \mathrm{BrCl}$ & $"$ & $\begin{array}{l}\text { Trincomalee } \\
\text { (Foul Point) Sri } \\
\text { Lanka }\end{array}$ \\
\hline [49] & & $\begin{array}{l}\text { 2-(1-chloro-2- } \\
\text { hydroxyethyl)-4,4- } \\
\text { dimethylcyclohexa-2, } \\
\text { 5-dienone: a precursor } \\
\text { of 4,5-dimethylbenzo } \\
\text { [b] furan }\end{array}$ & - & - & - \\
\hline \multirow[t]{6}{*}{ [20] } & 1 & $\begin{array}{l}(2 Z, 6 E) \text {-1,8-dichloro-3- } \\
\text { chloromethyl-7- } \\
\text { methylocta-2,6-diene }\end{array}$ & $\mathrm{C}_{10} \mathrm{H}_{15} \mathrm{Cl} 3$ & $\begin{array}{l}\text { acyclic } \\
\text { halogenated } \\
\text { monoterpene }\end{array}$ & $\begin{array}{l}\text { Rib Reef, Great } \\
\text { Barrier Reef, } \\
\text { Australia }\end{array}$ \\
\hline & 2 & $\begin{array}{l}\text { (E)-1,2-dibromo-3- } \\
\text { chloromethylene-7- } \\
\text { methyloct-6-ene }\end{array}$ & $\mathrm{C}_{10} \mathrm{H}_{15} \mathrm{Br}_{2} \mathrm{Cl}$ & $"$ & " \\
\hline & 3 & $\begin{array}{l}\text { (Z)-1-chloro-3- } \\
\text { chloromethyl-7- } \\
\text { methylocta-2,6-diene }\end{array}$ & $\mathrm{C}_{10} \mathrm{H}_{16} \mathrm{Cl} 2$ & $"$ & " \\
\hline & 4 & $\begin{array}{l}\text { (Z)-1,6-dichloro-3- } \\
\text { chloromethyl-7- } \\
\text { methylocta-2,7-diene }\end{array}$ & $\mathrm{C}_{10} \mathrm{H}_{15} \mathrm{Cl} 3$ & $"$ & $"$ \\
\hline & 5 & $\begin{array}{l}\left(2 R^{*}, 3(8) E, 4 S^{*}, 6 R^{*}\right)-6 \text { - } \\
\text { bromo-2-chloro-1,4- } \\
\text { oxido-3,(8)-ochtodene }\end{array}$ & $\mathrm{C}_{10} \mathrm{H}_{14} \mathrm{BrClO}$ & $\begin{array}{l}\text { epimeric bicyclic } \\
\text { monoterpene }\end{array}$ & $"$ \\
\hline & 6 & $\begin{array}{l}\left(2 S^{*}, 3(8) E, 4 S^{*}, 6 R^{*}\right)-6 \text { - } \\
\text { bromo-2-chloro-1,4- } \\
\text { oxido-3,(8)-ochtodene }\end{array}$ & $\mathrm{C}_{10} \mathrm{H}_{14} \mathrm{BrClO}$ & $"$ & $"$ \\
\hline [50] & & $\begin{array}{l}\text { (Z)-3-bromo-8-chloro- } \\
\text { 6-chloromethyl-2- } \\
\text { methylocta-1,6-diene } \\
\text { (9,6-hydroxymethyl-2- } \\
\text { methylocta-2,8-dien-6- } \\
\text { ol }\end{array}$ & - & - & - \\
\hline [21] & 1 & $\begin{array}{l}\text { (2Z)-6-bromo-3- } \\
\text { chloromethyl-1,7- } \\
\text { dichloro-7-methylocta- } \\
\text { 2-ene }\end{array}$ & $\mathrm{C}_{10} \mathrm{H}_{16} \mathrm{Cl}_{3} \mathrm{Br}$ & $\begin{array}{l}\text { acyclic } \\
\text { halogenated } \\
\text { monoterpene }\end{array}$ & $\begin{array}{l}\text { Nelly Bay, } \\
\text { Magnetic Island, } \\
\text { Queensland, } \\
\text { Australia }\end{array}$ \\
\hline
\end{tabular}


Table S1. Cont.

\begin{tabular}{|c|c|c|c|c|c|}
\hline & 2 & $\begin{array}{l}(2 Z, 6 E)-3- \\
\text { chloromethyl-1- } \\
\text { chloroocta-2,6-dien-8- } \\
\text { al }\end{array}$ & $\mathrm{C}_{10} \mathrm{H}_{14} \mathrm{OCl}_{2}$ & " & " \\
\hline & 3 & $\begin{array}{l}\text { 3-methoxymethyl-6- } \\
\text { methoxyl-7- } \\
\text { methylocta-1,7(10)- } \\
\text { dien-3-ol }\end{array}$ & $\mathrm{C}_{12} \mathrm{H}_{22} \mathrm{O}_{3}$ & $"$ & $"$ \\
\hline & 4 & $\begin{array}{l}(2 Z, 6 S)-3- \\
\text { chloromethyl-1- } \\
\text { methylocta-2,7(10)- } \\
\text { dien-6-ol }\end{array}$ & $\mathrm{C}_{11} \mathrm{H}_{19} \mathrm{O}_{2} \mathrm{Cl}$ & " & $"$ \\
\hline & 5 & $\begin{array}{l}(2 Z, 6 S)-3- \\
\text { chloromethyl-6- } \\
\text { methylocta-2,7(10)- } \\
\text { dien-1-ol }\end{array}$ & $\mathrm{C}_{11} \mathrm{H}_{19} \mathrm{O}_{2} \mathrm{Cl}$ & $"$ & " \\
\hline [22] & 1 & $\begin{array}{l}\text { halomon/6 }(R) \text {-bromo- } \\
3(S) \text {-(bromomethyl)-7- } \\
\text { methyl-2,3,7-trichloro- } \\
\text { 1-octene }\end{array}$ & $\mathrm{C}_{10} \mathrm{H}_{15} \mathrm{Br}_{2} \mathrm{Cl}_{3}$ & $\begin{array}{l}\text { acyclic } \\
\text { halogenated } \\
\text { monoterpene }\end{array}$ & $\begin{array}{l}\text { Chanaryan, Batan } \\
\text { Is., Batanes, } \\
\text { Philippines }\end{array}$ \\
\hline & 2 & - & $\mathrm{C}_{10} \mathrm{H}_{13} \mathrm{Cl}$ & $\begin{array}{l}\text { cyclic halogenated } \\
\text { monoterpene }\end{array}$ & $\begin{array}{l}\text { Banilad, Bacong, } \\
\text { Negros Oriental, } \\
\text { Philippines }\end{array}$ \\
\hline [23] & 2 & isohalomon & $\mathrm{C}_{10} \mathrm{H}_{15} \mathrm{Br}_{2} \mathrm{Cl}_{3}$ & $\begin{array}{l}\text { acyclic } \\
\text { halogenated } \\
\text { monoterpene; } \\
\text { isomeric with } \\
\text { halomon }\end{array}$ & $\begin{array}{l}\text { Chanaryan, Batan } \\
\text { Is., Batanes, } \\
\text { Philippines }\end{array}$ \\
\hline & 3 & - & $\mathrm{C}_{10} \mathrm{H}_{14} \mathrm{BrCl}_{3}$ & $\begin{array}{l}\text { acyclic } \\
\text { halogenated } \\
\text { monoterpene }\end{array}$ & " \\
\hline & 4 & - & $\mathrm{C}_{10} \mathrm{H}_{14} \mathrm{Br}_{2} \mathrm{Cl}_{2}$ & $"$ & $"$ \\
\hline & 5 & - & $\mathrm{C}_{10} \mathrm{H}_{14} \mathrm{Br}_{3} \mathrm{Cl}$ & $\begin{array}{l}\text { cyclic halogenated } \\
\text { monoterpene }\end{array}$ & $"$ \\
\hline & 6 & - & $\mathrm{C}_{10} \mathrm{H}_{14} \mathrm{BrCl}_{3}$ & $"$ & $"$ \\
\hline & 7 & - & $\mathrm{C}_{10} \mathrm{H}_{13} \mathrm{Cl}_{3}$ & $"$ & $"$ \\
\hline & 8 & - & $\mathrm{C}_{10} \mathrm{H}_{15} \mathrm{BrCl}_{2}$ & $\begin{array}{l}\text { acyclic } \\
\text { halogenated } \\
\text { monoterpene }\end{array}$ & $"$ \\
\hline & 9 & - & $\mathrm{C}_{10} \mathrm{H}_{16} \mathrm{Br}_{2} \mathrm{Cl}_{2}$ & 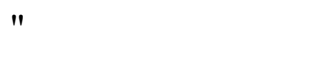 & " \\
\hline & 10 & - & $\mathrm{C}_{10} \mathrm{H}_{16} \mathrm{BrCl}$ & $"$ & $\begin{array}{l}\text { Halona Blowhole } \\
\text { Is, Oahu, Hawaii }\end{array}$ \\
\hline & 11 & - & $\mathrm{C}_{10} \mathrm{H}_{15} \mathrm{BrCl}$ & $"$ & " \\
\hline & 12 & - & $\mathrm{C}_{10} \mathrm{H}_{14} \mathrm{BrCl}$ & $\begin{array}{l}\text { cyclic halogenated } \\
\text { monoterpene }\end{array}$ & $"$ \\
\hline
\end{tabular}


Table S1. Cont.

\begin{tabular}{|c|c|c|c|c|c|}
\hline \multirow[t]{2}{*}{ [8] } & 1 & $\begin{array}{l}\text { apakaochtodene } \mathbf{A} / \\
6\left(S^{*}\right) \text {-bromo- } \\
1,4\left(S^{*}\right), 8\left(R^{*}\right) \text {-trichloro- } \\
2(\mathrm{Z}) \text {-ochtodene }\end{array}$ & $\mathrm{C}_{10} \mathrm{H}_{14} \mathrm{Cl}_{3} \mathrm{Br}$ & $\begin{array}{l}\text { cyclic halogenated } \\
\text { monoterpene }\end{array}$ & $\begin{array}{l}\text { Apaka Point } \\
\text { Beach, Guam }\end{array}$ \\
\hline & 2 & $\begin{array}{l}\text { apakaochtodene B/ } \\
6(S) \text {-bromo-1,4(S), } \\
8\left(R^{*}\right) \text {-trichloro-2(E)- } \\
\text { ochtodene }\end{array}$ & $\mathrm{C}_{10} \mathrm{H}_{14} \mathrm{Cl}_{3} \mathrm{Br}$ & $\begin{array}{l}\text { cyclic halogenated } \\
\text { monoterpene }\end{array}$ & $\begin{array}{l}\text { Gun Beach; } \\
\text { Double Reef; } \\
\text { Pago Bay; Guam }\end{array}$ \\
\hline \multirow[t]{15}{*}[11]{} & 1 & $\begin{array}{l}\text { myrcene/7-methyl-3- } \\
\text { methylene-1,6- } \\
\text { octadiene }\end{array}$ & $\mathrm{C}_{10} \mathrm{H}_{16} \mathrm{O}$ & $\begin{array}{l}\text { acyclic non- } \\
\text { halogenated } \\
\text { monoterpene }\end{array}$ & $\begin{array}{l}\text { microplantlet } \\
\text { culture, Double } \\
\text { Reef NW Guam }\end{array}$ \\
\hline & 2 & $\begin{array}{l}\mathbf{1 0 E} \text {-bromomyrcene/ } \\
E \text {-3-bromomethylene- } \\
\text { 7-methyl-1,6-octadiene }\end{array}$ & $\mathrm{C}_{10} \mathrm{H}_{15} \mathrm{Br}$ & $"$ & " \\
\hline & 3 & $\begin{array}{l}\text { 10Z-bromomyrcene/ } \\
\text { Z-3-bromomethylene- } \\
\text { 7-methyl-1,6-octadiene }\end{array}$ & $\mathrm{C}_{10} \mathrm{H}_{15} \mathrm{Br}$ & $"$ & $"$ \\
\hline & 4 & $\begin{array}{l}\text { 10E-bromo-3-chloro- } \\
\text { a-myrcene/ } E \text {-3- } \\
\text { bromomethylene-6- } \\
\text { chloro-1,7-octadiene }\end{array}$ & $\mathrm{C}_{10} \mathrm{H}_{14} \mathrm{BrCl}$ & $"$ & $"$ \\
\hline & 5 & - & $\mathrm{C}_{10} \mathrm{H}_{14} \mathrm{Br}_{2}$ & $"$ & $"$ \\
\hline & 6 & $\begin{array}{l}\text { apakaochtodene B/ } \\
6(S) \text {-bromo-1,4(S), } \\
8\left(R^{*}\right) \text {-trichloro-2(E)- } \\
\text { ochtodene }\end{array}$ & $\mathrm{C}_{10} \mathrm{H}_{14} \mathrm{BrCl}_{3}$ & $\begin{array}{l}\text { cyclic halogenated } \\
\text { monoterpene }\end{array}$ & " \\
\hline & 7 & - & $\mathrm{C}_{10} \mathrm{H}_{16} \mathrm{O}$ & $\begin{array}{l}\text { non-halogenated } \\
\text { monoterpene }\end{array}$ & " \\
\hline & 8 & bromomyrcene isomer & $\mathrm{C}_{10} \mathrm{H}_{15} \mathrm{Br}$ & $\begin{array}{l}\text { halogenated } \\
\text { monoterpene }\end{array}$ & $"$ \\
\hline & 9 & $\begin{array}{l}\text { 7-chloromyrcene/2- } \\
\text { chloro-3-methylene-7- } \\
\text { methyl-1,6-octadiene }\end{array}$ & $\mathrm{C}_{10} \mathrm{H}_{15} \mathrm{Cl}$ & 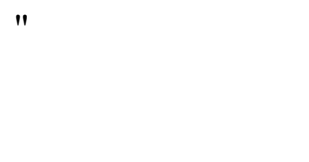 & $"$ \\
\hline & 10 & & $\mathrm{C}_{10} \mathrm{H}_{14} \mathrm{Cl}$ & $"$ & $"$ \\
\hline & 11 & $\begin{array}{l}\text { chloromyrcene } \\
\text { derivative }\end{array}$ & $\mathrm{C}_{10} \mathrm{H}_{16} \mathrm{Cl}$ & $"$ & $"$ \\
\hline & 12 & bromomyrcene isomer & $\mathrm{C}_{10} \mathrm{H}_{15} \mathrm{Br}$ & $"$ & $"$ \\
\hline & 13 & $\begin{array}{l}\text { chloromyrcene } \\
\text { derivative }\end{array}$ & $\mathrm{C}_{10} \mathrm{H}_{14} \mathrm{Cl}$ & $"$ & $"$ \\
\hline & 14 & - & $\mathrm{C}_{10} \mathrm{H}_{18} \mathrm{Cl}_{2}$ & $"$ & $"$ \\
\hline & 15 & - & $\mathrm{C}_{15} \mathrm{H}_{18} \mathrm{O}_{4}$ & sesquiterpene & " \\
\hline [13] & 5 & $\begin{array}{l}\text { 1,2-dibromoochtoda- } \\
\text { 3(8),5-dien-4-one }\end{array}$ & $\mathrm{C}_{22} \mathrm{H}_{12} \mathrm{Br}_{2} \mathrm{O}$ & $\begin{array}{l}\text { cyclic halogenated } \\
\text { monoterpene }\end{array}$ & $\begin{array}{l}\text { Cape Zampa, } \\
\text { Okinawa, Japan }\end{array}$ \\
\hline
\end{tabular}


Table S1. Cont.

\begin{tabular}{|c|c|c|c|c|c|}
\hline & 6 & $\begin{array}{l}\text { 1-bromo-2- } \\
\text { chloroochtoda-3(8),5- } \\
\text { dien-4-one }\end{array}$ & $\mathrm{C}_{10} \mathrm{H}_{12} \mathrm{BrClO}$ & " & " \\
\hline & 7 & $\begin{array}{l}\text { 1,2-dichloroochtoda- } \\
\text { 3(8),5-dien-4-one }\end{array}$ & $\mathrm{C}_{10} \mathrm{H}_{12} \mathrm{Cl}_{2} \mathrm{O}$ & " & $\begin{array}{l}\text { Gushichan coast, } \\
\text { Okinawa, Japan }\end{array}$ \\
\hline & 8 & $\begin{array}{l}\text { (1Z)-1-bromoochtoda- } \\
\text { 1,3(8),5-trien-4-one }\end{array}$ & $\mathrm{C}_{10} \mathrm{H}_{11} \mathrm{BrO}$ & $"$ & $\begin{array}{l}\text { Cape Zampa, } \\
\text { Okinawa, Japan }\end{array}$ \\
\hline & 9 & $\begin{array}{l}\text { (1Z)-1-chloroochtoda- } \\
\text { 1,3(8),5-trien-4-one }\end{array}$ & $\mathrm{C}_{10} \mathrm{H}_{11} \mathrm{ClO}$ & $"$ & " \\
\hline \multirow[t]{4}{*}{ [12] } & 1 & $\begin{array}{l}\text { halomon/6(R)-bromo- } \\
3(S) \text {-(bromomethyl)-7- } \\
\text { methyl-2,3,7-trichloro- } \\
\text { 1-octene }\end{array}$ & $\mathrm{C}_{10} \mathrm{H}_{15} \mathrm{Br}_{2} \mathrm{Cl}_{3}$ & $\begin{array}{l}\text { acyclic } \\
\text { halogenated } \\
\text { monoterpene }\end{array}$ & $\begin{array}{l}\text { Tolagniaro, Fort } \\
\text { Dauphin, } \\
\text { Madagascar }\end{array}$ \\
\hline & 2 & - & $\mathrm{C}_{10} \mathrm{H}_{13} \mathrm{ClBr}$ & " & $"$ \\
\hline & 3 & - & $\mathrm{C}_{10} \mathrm{H}_{14} \mathrm{Cl}_{2} \mathrm{Br}$ & $"$ & $"$ \\
\hline & 4 & & $\mathrm{C}_{10} \mathrm{H}_{15} \mathrm{Br}_{2} \mathrm{Cl}_{3}$ & " & $"$ \\
\hline
\end{tabular}

Table S2. Compound peaks detected from GC-MS analysis of samples used for characterization of the life history stages of $P$. hornemannii. Identifications based on comparison of either Kovat's Indices (KI) of compounds retrieved from the Retention Index Calculator [37] or mass spectral comparison of compounds retrieved from NIST or MassBase. Asterisk (*) indicates compounds with parent ions showing halogenated mass spectral patterns.

\begin{tabular}{|c|c|c|c|c|c|c|c|c|}
\hline \multirow[t]{2}{*}{ \# } & \multirow[t]{2}{*}{ Sample } & \multirow{2}{*}{$\begin{array}{l}\text { Base } \\
\text { Peak }\end{array}$} & \multirow[b]{2}{*}{ RT (min) } & \multirow[t]{2}{*}{ KI } & \multicolumn{2}{|c|}{ KI Based ID } & \multicolumn{2}{|c|}{ Mass Spectra Based ID } \\
\hline & & & & & $\begin{array}{l}\text { Nearest } \\
\text { KI }\end{array}$ & Lucero et al. [37] & NIST & MassBase \\
\hline 1 & F6_2 & 93 & 6.1863 & 994 & $993 / 994$ & $\begin{array}{l}\text { beta-myrcene/6- } \\
\text { methyl-5-hepten-2-ol }\end{array}$ & b-myrcene & b-myrcene \\
\hline 2 & $\mathrm{~T} 1 \_1$ & 104 & 6.5874 & 1008 & 1007 & $\alpha$-phellandrene & - & - \\
\hline 3 & T1_2 & 104 & 6.5909 & 1008 & 1007 & $\alpha$-phellandrene & - & - \\
\hline 4 & M1_1 & 91 & 6.7685 & 1016 & 1017 & $\alpha$-terpinene & $\begin{array}{l}\text { Benzene, } \\
\text { tert-butyl- }\end{array}$ & $\begin{array}{l}\text { 4- } \\
\text { methylacetophenone }\end{array}$ \\
\hline 5 & F3_3 & 79 & 6.9501 & 1023 & 1024 & r-cymene & - & - \\
\hline 6 & M1_2 & 79 & 6.9532 & 1023 & 1024 & r-cymene & - & - \\
\hline 7 & M1_3 & 91 & 7.017 & 1026 & 1025 & p-cymene & carbonic acid & $\begin{array}{l}\text { 1-phenylpropan-2- } \\
\text { one }\end{array}$ \\
\hline 8 & M2_2 & 91 & 7.021 & 1026 & 1025 & p-cymene & - & protopine \\
\hline 9 & F3_2 & 91 & 7.0387 & 1027 & 1025 & p-cymene & - & $\begin{array}{l}N \text {-Methyl- } N \text { - } \\
\text { propagylbenzylamine }\end{array}$ \\
\hline 10 & $\mathrm{~T} 2 \_1$ & 57 & 8.0381 & 1063 & 1062 & y-terpinene & - & - \\
\hline 11 & M2_2 & 132 & 8.8894 & 1089 & 1089 & $\begin{array}{l}\text { p-mentha- } \\
\text { 2,4(8)diene }\end{array}$ & - & - \\
\hline
\end{tabular}


Table S2. Cont.

\begin{tabular}{|c|c|c|c|c|c|c|c|c|}
\hline 12 & T2_1 & 117 & 9.5127 & 1110 & 1099 & linalool & - & - \\
\hline 13 & F4_3 & 117 & 9.8874 & 1124 & 1123 & chrysanthenone & - & - \\
\hline 14 & M1_3 & 117 & 9.9855 & 1128 & 1127 & $\alpha$-campholenal & - & - \\
\hline 15 & M2_2 & 91 & 10.2042 & 1136 & 1127 & $\alpha$-campholenal & - & - \\
\hline 16 & F2_2 & 91 & 10.2132 & 1136 & 1127 & $\alpha$-campholenal & - & Dimethirimol \\
\hline 17 & T2_1 & 119 & 10.4565 & 1145 & 1145 & camphor & - & Benzimidazole \\
\hline 18 & M1_1 & 68 & 10.8826 & 1160 & 1158 & isobomeol & - & - \\
\hline 19 & F7_3 & 68 & 10.8845 & 1160 & 1158 & isobomeol & - & - \\
\hline 20 & T2_1 & 68 & 10.8866 & 1160 & 1158 & isobomeol & - & - \\
\hline 21 & F3_3 & 68 & 10.8873 & 1160 & 1158 & isobomeol & - & - \\
\hline 22 & F4_1 & 117 & 11.3242 & 1174 & 1171 & ethyl-benzoate & - & - \\
\hline 23 & F4_1 & 50 & 11.5177 & 1180 & 1180 & m-cymen-8-ol & - & - \\
\hline 24 & $\mathrm{~T} 2 \_2$ & 127 & 11.5317 & 1180 & 1180 & m-cymen-8-ol & - & - \\
\hline 25 & $\mathrm{~T} 2 \_3$ & 134 & 11.7619 & 1188 & 1187 & p-cymen-8-ol & - & - \\
\hline 26 & M2_2 & 105 & 12.0654 & 1197 & 1196 & methylchavicol & - & 3-cyanopyridine \\
\hline 27 & F3_2 & 57 & 12.1827 & 1200 & 1203 & n-decanal & 3-Hexanone & - \\
\hline 28 & F7_3 & 113 & 12.3674 & 1207 & 1207 & verbenone & - & - \\
\hline 29 & M1_2 & 113 & 12.3831 & 1208 & 1207 & verbenone & - & - \\
\hline 30 & T1_3 & 91 & 12.3874 & 1208 & 1207 & verbenone & - & - \\
\hline 31 & M2_2 & 93 & 12.6294 & 1217 & 1217 & trans-carveol & - & - \\
\hline 32 & M1_2 & 69 & 12.7588 & 1222 & 1219 & trans-carveol & - & - \\
\hline 33 & M1_1 & 55 & 12.8397 & 1225 & 1229 & nerol & - & - \\
\hline 34 & F7_3 & 67 & 13.1203 & 1236 & 1236 & thymol methyl ether & - & - \\
\hline 35 & M1_1 & 79 & 13.1266 & 1236 & 1236 & thymol methyl ether & - & - \\
\hline 36 & F5_2 & 93 & 13.127 & 1236 & 1236 & thymol methyl ether & - & $\begin{array}{l}\text { Beta-pinene; } \\
\text { y-eudesmol }\end{array}$ \\
\hline 37 & M2_2 & 93 & 13.32 & 1243 & 1243 & carvone & - & - \\
\hline 38 & T1_1 & 93 & 13.327 & 1243 & 1243 & carvone & $\begin{array}{l}\text { 2- } \\
\text { chloropropionyl } \\
\text { chloride }\end{array}$ & - \\
\hline 39 & T2_1 & 93 & 13.3305 & 1243 & 1243 & carvone & - & - \\
\hline 40 & F6_2 & 69 & 13.6916 & 1256 & 1256 & geraniol & - & - \\
\hline$*(\mathrm{Br}$ & & & & & & & & \\
\hline 41 & M1_1 & 91 & 13.6953 & 1256 & 1256 & geraniol & & - \\
\hline 42 & F2_1 & 69 & 13.6967 & 1256 & 1256 & geraniol & - & \\
\hline 43 & F5_1 & 69 & 13.6975 & 1256 & 1256 & geraniol & - & - \\
\hline 44 & M2_1 & 91 & 13.9837 & 1266 & 1263 & (E)-2-decenal & - & $\begin{array}{l}N \text {-Methyl- } N \text { - } \\
\text { propagylbenzylamin } \\
\text { e }\end{array}$ \\
\hline 45 & F7_3 & 119 & 14.131 & 1271 & 1271 & geranial & - & - \\
\hline 46 & F2_3 & 119 & 14.1354 & 1271 & 1271 & geranial & - & - \\
\hline 47 & F3_2 & 69 & 14.4252 & 1281 & 1282 & a-terpinen-7-al & - & - \\
\hline 48 & M2_3 & 69 & 14.4368 & 1281 & 1282 & a-terpinen-7-al & - & - \\
\hline 49 & F5_1 & 91 & 14.6745 & 1289 & 1289 & p-cymen-7-ol & - & - \\
\hline
\end{tabular}


Table S2. Cont.

\begin{tabular}{|c|c|c|c|c|c|c|c|c|}
\hline 50 & T2_1 & 91 & 14.68 & 1289 & 1289 & p-cymen-7-ol & - & - \\
\hline 51 & F6_3 & 149 & 14.9157 & 1297 & 1297 & perilla alcohol & - & Benzoylcholine \\
\hline $\begin{array}{l}52 * \\
(\mathrm{Cl})\end{array}$ & F6_3 & 131 & 15.0641 & 1302 & 1302 & trans-ascaridole & - & $\begin{array}{l}\text { 2-chloro-1-phenyl- } \\
\text { 2-butene }\end{array}$ \\
\hline 53 & F6_1 & 166 & 15.3344 & 1313 & 1313 & $2 E, 4 E$-decadienal & - & $\begin{array}{l}\text { 2-chloro-1-phenyl- } \\
\text { 2-butene }\end{array}$ \\
\hline 54 & F6_3 & 81 & 15.5368 & 1320 & 1313 & $2 E, 4 E$-decadienal & - & - \\
\hline 55 & M2_2 & 81 & 15.5381 & 1321 & 1313 & $2 E, 4 E$-decadienal & - & - \\
\hline 56 & T1_2 & 81 & 15.5481 & 1321 & 1313 & $2 E, 4 E$-decadienal & - & - \\
\hline 57 & M2_2 & 67 & 15.6269 & 1324 & 1313 & $2 E, 4 E$-decadienal & - & 1-Adamantanamine \\
\hline 58 & M1_2 & 67 & 15.6354 & 1324 & 1313 & $2 E, 4 E$-decadienal & - & - \\
\hline 59 & F3_1 & 57 & 15.7447 & 1329 & 1339 & d-elemene & - & - \\
\hline 60 & F2_1 & 57 & 15.7649 & 1329 & 1339 & d-elemene & - & - \\
\hline 61 & M2_2 & 91 & 15.8827 & 1334 & 1339 & d-elemene & - & - \\
\hline 62 & M1_2 & 91 & 15.8885 & 1334 & 1339 & d-elemene & - & - \\
\hline 63 & M2_2 & 139 & 16.5157 & 1357 & 1357 & eugenol & - & - \\
\hline 64 & F6_1 & 115 & 16.5278 & 1358 & 1357 & eugenol & - & - \\
\hline 65 & M2_3 & 166 & 16.5392 & 1358 & 1357 & eugenol & - & - \\
\hline 66 & M2_2 & 91 & 17.02 & 1375 & 1373 & a-ylangene & - & - \\
\hline 67 & M2_3 & 91 & 17.0254 & 1376 & 1373 & a-ylangene & - & - \\
\hline 68 & M1_2 & 91 & 17.0311 & 1376 & 1373 & a-ylangene & - & - \\
\hline 69 & $\mathrm{~T} 2 \_1$ & 127 & 17.403 & 1389 & 1389 & isolongifolene & - & Imidazole-4-acetate \\
\hline 70 & T2_1 & 57 & 17.7476 & 1400 & 1399 & 1,7-di-epi-a-cedrene & - & - \\
\hline 71 & M2_2 & 79 & 17.7625 & 1401 & 1402 & methyleugenol & - & - \\
\hline 72 & M2_3 & 127 & 17.7782 & 1402 & 1402 & methyleugenol & - & - \\
\hline 73 & $\mathrm{~T} 2 \_2$ & 67 & 18.1041 & 1415 & 1415 & cis-a-bergarnotene & - & - \\
\hline 74 & T1_3 & 79 & 18.18 & 1418 & 1419 & $\beta$-caryophyllene & - & - \\
\hline 75 & F6_1 & 79 & 18.1866 & 1419 & 1419 & $\beta$-caryophyllene & - & - \\
\hline 76 & T1_1 & 79 & 18.1928 & 1419 & 1419 & $\beta$-caryophyllene & Pyridine & - \\
\hline 77 & F5_1 & 79 & 18.1934 & 1419 & 1419 & $\beta$-caryophyllene & - & camphene \\
\hline 78 & M1_2 & 79 & 18.1939 & 1419 & 1419 & $\beta$-caryophyllene & - & - \\
\hline $\begin{array}{l}79 * \\
(\mathrm{Br})\end{array}$ & F7_2 & 212 & 18.3193 & 1424 & 1420 & $\beta$-caroyophyllene & - & - \\
\hline 80 & F6_2 & 210 & 18.4564 & 1429 & 1420 & $\beta$-caroyophyllene & - & - \\
\hline 81 & M2_3 & 131 & 18.4673 & 1430 & 1420 & $\beta$-caroyophyllene & - & - \\
\hline 82 & M1_1 & 67 & 18.5462 & 1433 & 1435 & trans-a-bergamotene & - & - \\
\hline 83 & M1_2 & 67 & 18.5503 & 1433 & 1435 & trans-a-bergamotene & - & - \\
\hline 84 & F2_2 & 133 & 18.6084 & 1435 & 1435 & trans-a-bergamotene & - & - \\
\hline 85 & T2_2 & 69 & 18.6925 & 1439 & 1438 & trans-a-bergamotene & - & - \\
\hline 86 & F3_3 & 69 & 18.6982 & 1439 & 1440 & a-guaiene & - & - \\
\hline 87 & M2_3 & 69 & 18.7018 & 1439 & 1440 & a-guaiene & - & - \\
\hline 88 & M1_1 & 91 & 18.7475 & 1441 & 1440 & a-guaiene & - & - \\
\hline 89 & F4_2 & 69 & 18.8243 & 1444 & 1440 & a-guaiene & - & - \\
\hline
\end{tabular}


Table S2. Cont.

\begin{tabular}{|c|c|c|c|c|c|c|c|c|}
\hline 90 & F7_2 & 69 & 18.8273 & 1444 & 1440 & a-guaiene & - & - \\
\hline 91 & T1_3 & 69 & 18.8306 & 1444 & 1440 & a-guaiene & - & - \\
\hline 92 & F2_2 & 210 & 19.1226 & 1456 & 1455 & a-humulene & - & - \\
\hline 93 & F3_3 & 133 & 19.3339 & 1464 & 1464 & a-acoradiene & - & \\
\hline 94 & $\mathrm{~T} 2 \_2$ & 105 & 19.4843 & 1469 & 1469 & drima-7,9(11)-diene & - & - \\
\hline 95 & $\mathrm{~T} 2 \_1$ & 105 & 19.4852 & 1469 & 1469 & drima-7,9(11)-diene & - & - \\
\hline 96 & F7_2 & 131 & 19.4915 & 1470 & 1469 & drima-7,9(11)-diene & - & - \\
\hline 97 & F5_1 & 91 & 19.6255 & 1475 & 1474 & b-cadinene & - & - \\
\hline 98 & F6_3 & 91 & 19.7468 & 1479 & 1479 & y-curcurnene & - & \\
\hline 99 & F2_1 & 91 & 19.7581 & 1480 & 1480 & germacrene D & - & - \\
\hline 100 & F4_1 & 153 & 20.0567 & 1491 & 1491 & cis- $\beta$-guaiene & - & - \\
\hline 101 & F4_1 & 153 & 20.0567 & 1491 & 1491 & cis- $\beta$-guaiene & - & - \\
\hline 102 & F3_2 & 71 & 20.2111 & 1496 & 1495 & a-zingiberene & - & \\
\hline 103 & F7_2 & 135 & 20.3621 & 1502 & 1499 & a-muurolene & - & - \\
\hline 104 & F5_1 & 91 & 20.3727 & 1503 & 1506 & d-selinene & - & - \\
\hline 105 & T2_1 & 91 & 20.3766 & 1503 & 1506 & $\mathrm{~d}$-selinene & - & - \\
\hline 106 & $\mathrm{~F} 2 \_2$ & 91 & 20.3829 & 1503 & 1506 & d-selinene & -- & - \\
\hline 107 & F6_1 & 205 & 20.6221 & 1513 & 1513 & g-cadinene & - & - \\
\hline 108 & F4_3 & 205 & 20.6237 & 1513 & 1513 & g-cadinene & - & - \\
\hline 109 & F7_2 & 205 & 20.6252 & 1513 & 1513 & g-cadinene & - & $\begin{array}{l}\text { 5-bromo-4- } \\
\text { methoxyoct-1-ene }\end{array}$ \\
\hline 110 & T2_1 & 205 & 20.6278 & 1513 & 1513 & g-cadinene & p-Benzoquinone & - \\
\hline 111 & F3_2 & 133 & 20.6781 & 1516 & 1514 & sesquicineole & - & - \\
\hline 112 & F3_3 & 133 & 20.6803 & 1516 & 1514 & sesquicineole & - & - \\
\hline 113 & F6_3 & 133 & 20.685 & 1516 & 1514 & sesquicineole & - & - \\
\hline 114 & F5_1 & 69 & 20.8293 & 1522 & 1523 & d-cadinene & - & -- \\
\hline 115 & F5_1 & 69 & 20.9154 & 1526 & 1525 & eugenyl acetate & - & - \\
\hline 116 & F6_3 & 69 & 20.9158 & 1526 & 1525 & eugenyl acetate & - & - \\
\hline 117 & F7_2 & 121 & 20.9204 & 1526 & 1525 & eugenyl acetate & - & - \\
\hline 118 & T1_3 & 69 & 20.9227 & 1526 & 1525 & eugenyl acetate & - & - \\
\hline 119 & F7_2 & 167 & 21.1103 & 1534 & 1533 & cadina-1,4-diene1 & - & - \\
\hline 120 & T2_2 & 91 & 21.1498 & 1536 & 1538 & a-cadinene & - & - \\
\hline 121 & F6_1 & 167 & 21.43 & 1547 & 1548 & elemol & - & - \\
\hline 122 & F7_2 & 167 & 21.4346 & 1547 & 1548 & elemol & - & - \\
\hline 123 & T1_3 & 69 & 21.467 & 1549 & 1549 & elemol & - & -- \\
\hline 124 & F3_2 & 69 & 21.4709 & 1549 & 1549 & elemol & - & - \\
\hline 125 & F7_2 & 91 & 21.598 & 1554 & 1552 & elemicin & - & - \\
\hline 126 & F6_2 & 91 & 21.6852 & 1557 & 1557 & germacrene B & - & - \\
\hline 127 & F5_1 & 91 & 21.6859 & 1558 & 1557 & germacrene B & - & - \\
\hline 128 & F6_3 & 91 & 21.6869 & 1558 & 1557 & germacrene B & - & - \\
\hline 129 & M1_1 & 91 & 21.6895 & 1558 & 1557 & germacrene B & - & - \\
\hline 130 & F6_3 & 67 & 21.7268 & 1559 & 1557 & germacrene B & - & - \\
\hline 131 & F7_2 & 133 & 21.8253 & 1563 & 1564 & $\beta$-calacorene & - & L-Asparagine \\
\hline 132 & $\mathrm{~T} 1 \_1$ & 91 & 21.8405 & 1564 & 1564 & $\beta$-calacorene & - & - \\
\hline 133 & F7_2 & 167 & 22.0012 & 1570 & 1574 & prenopsan-8-ol & - & - \\
\hline
\end{tabular}


Table S2. Cont.

\begin{tabular}{|c|c|c|c|c|c|c|c|c|}
\hline 134 & T1_3 & 213 & 22.018 & 1571 & 1574 & prenopsan-8-ol & - & - \\
\hline 135 & F6_3 & 132 & 22.0226 & 1571 & 1574 & prenopsan-8-ol & - & - \\
\hline 136 & F6_3 & 153 & 22.0226 & 1571 & 1574 & prenopsan-8-ol & - & - \\
\hline 137 & M1_1 & 91 & 22.3956 & 1586 & 1585 & gleenol & - & - \\
\hline 138 & F2_2 & 133 & 22.5362 & 1591 & 1590 & viridflorol & - & - \\
\hline 139 & F6_3 & 71 & 22.7179 & 1598 & 1590 & viridflorol & - & - \\
\hline 140 & F3_2 & 71 & 22.7193 & 1598 & 1590 & viridflorol & - & - \\
\hline 141 & F2_3 & 135 & 22.722 & 1598 & 1590 & viridflorol & - & - \\
\hline 142 & F3_3 & 57 & 22.7547 & 1600 & 1607 & b-oplopenone & - & - \\
\hline 143 & F3_2 & 57 & 22.7603 & 1600 & 1607 & b-oplopenone & - & - \\
\hline 144 & F3_3 & 57 & 22.761 & 1600 & 1607 & b-oplopenone & - & - \\
\hline 145 & F6_3 & 67 & 22.8782 & 1605 & 1607 & b-oplopenone & - & - \\
\hline 146 & $\mathrm{~T} 2 \_2$ & 68 & 23.0541 & 1613 & 1612 & tetradecanal & - & - \\
\hline 147 & F4_3 & 148 & 23.2435 & 1622 & 1623 & $\begin{array}{l}\text { silphiperfol-6-en-5- } \\
\text { one }\end{array}$ & - & - \\
\hline 148 & F3_1 & 135 & 23.2485 & 1622 & 1623 & $\begin{array}{l}\text { silphiperfol-6-en-5- } \\
\text { one }\end{array}$ & - & - \\
\hline 149 & F5_3 & 91 & 23.52 & 1634 & 1633 & y-eudesmol & - & - \\
\hline 150 & F4_3 & 91 & 23.5226 & 1634 & 1633 & y-eudesmol & - & - \\
\hline 151 & F7_2 & 68 & 23.5261 & 1634 & 1633 & y-eudesmol & - & - \\
\hline 152 & F7_2 & 68 & 23.5261 & 1634 & 1633 & y-eudesmol & - & -- \\
\hline 153 & T2_2 & 68 & 23.5278 & 1634 & 1633 & y-eudesmol & - & - \\
\hline 154 & F6_1 & 167 & 23.5309 & 1634 & 1633 & y-eudesmol & - & \\
\hline 155 & F6_2 & 67 & 23.7239 & 1643 & 1642 & cubenol & - & allylcy-anide \\
\hline 156 & T1_3 & 91 & 23.8325 & 1647 & 1646 & a-muurolol & - & - \\
\hline 157 & F7_2 & 132 & 23.8759 & 1649 & 1646 & a-muurolol & - & - \\
\hline 158 & F7_2 & 132 & 23.9988 & 1654 & 1653 & a-cadinol & - & - \\
\hline 159 & F6_2 & 149 & 24.3377 & 1669 & 1668 & bulnesol & - & - \\
\hline 160 & F7_2 & 149 & 24.3428 & 1669 & 1668 & bulnesol & - & - \\
\hline 161 & F6_3 & 167 & 24.6091 & 1680 & 1682 & a-bisabolol & - & - \\
\hline 162 & F6_1 & 57 & 24.6252 & 1681 & 1682 & a-bisabolol & - & - \\
\hline 163 & F7_2 & 69 & 24.8113 & 1689 & 1686 & 8-cedren-13-ol & - & - \\
\hline 164 & F7_2 & 69 & 24.8207 & 1689 & 1686 & 8-cedren-13-ol & - & - \\
\hline 165 & F2_3 & 67 & 24.9282 & 1693 & 1686 & 8-cedren-13-ol & - & - \\
\hline 166 & F6_1 & 57 & 25.0854 & 1700 & 1686 & 8-cedren-13-ol & - & Heptadecane \\
\hline 167 & F7_2 & 91 & 25.3006 & 1710 & 1686 & 8-cedren-13-ol & - & - \\
\hline 168 & F3_2 & 71 & 25.3224 & 1711 & 1735 & oplopanone & - & - \\
\hline 169 & F3_3 & 68 & 25.4814 & 1718 & 1735 & oplopanone & - & - \\
\hline 170 & F6_3 & 67 & 25.7278 & 1730 & 1735 & oplopanone & - & - \\
\hline 171 & F7_2 & 103 & 25.7292 & 1730 & 1735 & oplopanone & - & - \\
\hline 172 & F2_1 & 67 & 25.7318 & 1730 & 1735 & oplopanone & - & - \\
\hline 173 & $\mathrm{~F} 2 \_3$ & 133 & 25.8305 & 1735 & 1735 & oplopanone & - & - \\
\hline 174 & F3_1 & 117 & 25.8366 & 1735 & 1735 & oplopanone & - & - \\
\hline 175 & F7_2 & 167 & 26.3223 & 1757 & 1761 & benzyl-benzoate & - & - \\
\hline
\end{tabular}


Table S2. Cont.

\begin{tabular}{|c|c|c|c|c|c|c|c|c|}
\hline 176 & T2_1 & 167 & 26.5838 & 1769 & 1761 & benzyl-benzoate & - & $\begin{array}{l}\text { 6-Methylmer- } \\
\text { captopurine }\end{array}$ \\
\hline 177 & F6_2 & 117 & 26.7333 & 1775 & 1789 & 8-a-acetoxyelemol & - & - \\
\hline 178 & T2_2 & 103 & 26.8111 & 1779 & 1789 & 8-a-acetoxyelemol & - & - \\
\hline 179 & F3_1 & 67 & 26.8577 & 1781 & 1789 & 8-a-acetoxyelemol & - & - \\
\hline 180 & F6_1 & 67 & 26.8599 & 1781 & 1789 & 8-a-acetoxyelemol & - & - \\
\hline 181 & F3_2 & 67 & 26.8671 & 1781 & 1789 & 8 -a-acetoxyelemol & - & - \\
\hline 182 & T2_1 & 67 & 26.8697 & 1781 & 1789 & 8-a-acetoxyelemol & - & - \\
\hline $\begin{array}{l}183 * \\
\left(\mathrm{Cl}_{2}\right)\end{array}$ & F6_1 & 103 & 26.8838 & 1782 & 1789 & 8-a-acetoxyelemol & - & - \\
\hline 184 & F3_1 & 103 & 26.8852 & 1782 & 1789 & 8-a-acetoxyelemol & - & - \\
\hline $\begin{array}{l}185 * \\
(\mathrm{Br})\end{array}$ & F6_1 & 67 & 27.4286 & 1806 & 1798 & nootkatone & - & - \\
\hline $\begin{array}{l}186 * \\
(\mathrm{Br})\end{array}$ & F7_2 & 67 & 27.4342 & 1806 & 1798 & nootkatone & - & - \\
\hline 187 & F2_1 & 67 & 27.4383 & 1807 & 1798 & nootkatone & - & - \\
\hline 188 & F6_3 & 103 & 27.4961 & 1810 & 1798 & nootkatone & - & - \\
\hline 189 & F6_1 & 67 & 27.5012 & 1810 & 1798 & nootkatone & - & - \\
\hline 190 & F6_2 & 67 & 27.5676 & 1813 & 1827 & $\begin{array}{l}\text { isopropyl } \\
\text { tetradecanoate }\end{array}$ & - & - \\
\hline 191 & F6_2 & 69 & 28.0351 & 1836 & 1827 & $\begin{array}{l}\text { isopropyl } \\
\text { tetradecanoate }\end{array}$ & - & - \\
\hline 192 & F3_2 & 69 & 28.0387 & 1836 & 1827 & $\begin{array}{l}\text { isopropyl } \\
\text { tetradecanoate }\end{array}$ & - & - \\
\hline 193 & F6_1 & 91 & 28.3153 & 1849 & 1867 & flourensiadiol & - & - \\
\hline 194 & F3_2 & 149 & 28.735 & 1869 & 1867 & flourensiadiol & - & - \\
\hline $\begin{array}{l}195 * \\
(\mathrm{ClBr})\end{array}$ & F6_2 & 69 & 29.2918 & 1895 & 1878 & hexadecanol & - & - \\
\hline 196 & F5_3 & 67 & 29.4766 & 1903 & 1927 & $\begin{array}{l}\text { methyl } \\
\text { hexadecanoate }\end{array}$ & - & - \\
\hline 197 & T2_1 & 67 & 29.4889 & 1904 & 1927 & $\begin{array}{l}\text { methyl } \\
\text { hexadecanoate }\end{array}$ & - & - \\
\hline 198 & F7_2 & 91 & 30.7705 & 1968 & 1999 & eicosane & - & - \\
\hline 199 & T2_2 & 91 & 30.7753 & 1969 & 1999 & eicosane & - & - \\
\hline 200 & F3_2 & 91 & 30.7855 & 1969 & 1999 & eicosane & - & - \\
\hline 201 & $\mathrm{~T} 2 \_2$ & 64 & 31.6475 & - & - & - & - & - \\
\hline 202 & $\mathrm{~T} 2 \_2$ & 129 & 38.661 & - & - & - & - & - \\
\hline
\end{tabular}


Table S3. Compound peaks detected from GC-MS analysis of samples for evaluation of non-polar secondary metabolite patterns of 5 cryptic species of $P$. hornemanni found in Batanes, Philippines. Identifications based on comparison of either Kovat's Indices (KI) of compounds retrieved from the Retention Index Calculator [37] or mass spectral comparison of compounds retrieved from NIST or MassBase. Asterisk (*) indicates compounds with parent ions showing halogenated mass spectral patterns.

\begin{tabular}{|c|c|c|c|c|c|c|c|c|}
\hline \multirow[t]{2}{*}{ \# } & \multirow[t]{2}{*}{ Sample } & \multirow{2}{*}{$\begin{array}{l}\text { Base } \\
\text { Peak }\end{array}$} & \multirow[b]{2}{*}{$\begin{array}{l}\text { RT } \\
(\min )\end{array}$} & \multirow[t]{2}{*}{ KI } & \multicolumn{2}{|c|}{ KI Based ID } & \multicolumn{2}{|c|}{ Mass Spectra Based ID } \\
\hline & & & & & $\begin{array}{l}\text { Nearest } \\
\text { KI }\end{array}$ & Lucero et al. [37] & NIST & Massbase \\
\hline 1 & B4B & 57 & 8.1122 & 1065 & 1062 & y-terpinene & - & - \\
\hline 2 & $\mathrm{~B} 4 \mathrm{C}$ & 69 & 8.7386 & 1085 & 1085 & artemisia-alcohol & - & - \\
\hline 3 & B4C & 57 & 9.1807 & 1098 & 1097 & linalool & - & - \\
\hline 4 & B4B & 71 & 9.1841 & 1098 & 1097 & linalool & - & - \\
\hline 5 & $\mathrm{~B} 6 \mathrm{C}$ & 57 & 9.4047 & 1106 & 1099 & linalool & $\begin{array}{l}\text { 3-hexanone, } \\
\text { 2,2-dimethyl- }\end{array}$ & 2-methylbutane \\
\hline 6 & B4C & 69 & 11.2515 & 1172 & 1171 & ethyl-benzoate & - & - \\
\hline $\begin{array}{l}7-* \\
(\mathrm{Cl})\end{array}$ & B3A & 69 & 11.2560 & 1172 & 1171 & ethyl-benzoate & - & - \\
\hline 8 & $\mathrm{~B} 4 \mathrm{~A}$ & 57 & 14.3547 & 1279 & 1277 & $\begin{array}{l}\text { trans-carvone- } \\
\text { oxide }\end{array}$ & - & 2,2-dimethylbutane \\
\hline 9 & $\mathrm{~B} 4 \mathrm{~B}$ & 57 & 14.3593 & 1279 & 1277 & $\begin{array}{l}\text { trans-carvone- } \\
\text { oxide }\end{array}$ & - & 3-ethylhexane \\
\hline 10 & $\mathrm{~B} 3 \mathrm{~B}$ & 57 & 14.5560 & 1285 & 1286 & borneol-acetate & - & \\
\hline 11 & B3A & 69 & 15.2678 & 1310 & 1306 & undecanal & - & trans-4-octene \\
\hline 12 & B3A & 57 & 15.6497 & 1325 & 1314 & $2 E, 4 E$-decadienal & - & \\
\hline 13 & B6B & 57 & 15.6518 & 1325 & 1314 & $2 E, 4 E$-decadienal & - & \\
\hline 14 & B4A & 71 & 16.5884 & 1360 & 1357 & eugenol & - & 2-methylpentane \\
\hline 15 & $\mathrm{~B} 6 \mathrm{C}$ & 57 & 17.8154 & 1403 & 1403 & italicene & - & 2,2-dimethylbutane \\
\hline 16 & B3A & 57 & 17.8289 & 1404 & 1403 & italicene & - & \\
\hline 17 & $\mathrm{~B} 10$ & 71 & 20.306 & 1500 & 1499 & a-muurolene & - & Pentacosane \\
\hline 18 & B3A & 57 & 20.4025 & 1504 & 1506 & d-selinene & - & tripropylamine \\
\hline 19 & B4A & 191 & 20.715 & 1517 & 1514 & sesquicineole & - & \\
\hline 20 & $\mathrm{~B} 6 \mathrm{C}$ & 57 & 21.0008 & 1529 & 1532 & cadina-1,4-diene & - & \\
\hline $\begin{array}{l}21-* \\
(\mathrm{Br})\end{array}$ & B3B & 57 & 21.0024 & 1529 & 1532 & cadina-1,4-diene & - & 1-octene \\
\hline 22 & B4A & 69 & 21.5566 & 1552 & 1552 & elemicin & - & \\
\hline 23 & $\mathrm{~B} 4 \mathrm{~A}$ & 57 & 25.1819 & 1704 & 1686 & 8-cedren-13-ol & - & \\
\hline 24 & B4B & 71 & 25.4142 & 1715 & 1735 & oplopanone & - & Hexacosane \\
\hline 25 & B4B & 69 & 26.0498 & 1745 & 1747 & $6 S-7 R$-bisabolone & - & $\begin{array}{l}\text { 10-methyl-1- } \\
\text { dodecanol }\end{array}$ \\
\hline 26 & B4A & 57 & 27.4031 & 1805 & 1798 & nootkatone & - & 4-methyl-1-pentene \\
\hline 27 & B3B & 57 & 27.9515 & 1832 & 1827 & $\begin{array}{l}\text { isopropyl- } \\
\text { tetradecanoate }\end{array}$ & - & 2,4-dimethylpentane \\
\hline 28 & B3B & 71 & 29.9932 & 1930 & 1927 & $\begin{array}{l}\text { methyl- } \\
\text { hexadecanoate }\end{array}$ & - & docosane \\
\hline
\end{tabular}


Table S3. Cont.

\begin{tabular}{|c|c|c|c|c|c|c|c|c|}
\hline 29 & B6B & 57 & 30.4182 & 1951 & 1927 & $\begin{array}{l}\text { methyl- } \\
\text { hexadecanoate }\end{array}$ & - & - \\
\hline 30 & B10 & 69 & 30.5987 & 1960 & 1927 & $\begin{array}{l}\text { methyl- } \\
\text { hexadecanoate }\end{array}$ & - & - \\
\hline 31 & $\mathrm{~B} 4 \mathrm{C}$ & 73 & 30.6949 & 1965 & 1999 & eicosane & - & - \\
\hline 32 & $\mathrm{~B} 6 \mathrm{~B}$ & 71 & 32.0267 & & - & - & $\begin{array}{l}\text { 3-hexanone, } \\
\text { 2,2-dimethyl- }\end{array}$ & 2,2-dimethylbutane \\
\hline 33 & $\mathrm{~B} 3 \mathrm{~B}$ & 71 & 32.0458 & & - & - & - & 2,2-dimethylbutane \\
\hline 34 & B6B & 69 & 34.1452 & & - & - & - & docosane \\
\hline 35 & B3B & 69 & 34.7128 & & - & - & - & - \\
\hline 36 & $\mathrm{~B} 4 \mathrm{C}$ & 69 & 34.7233 & & - & - & - & - \\
\hline 37 & $\mathrm{~B} 6 \mathrm{C}$ & 71 & 35.0713 & & - & - & - & - \\
\hline 38 & $\mathrm{~B} 3 \mathrm{C}$ & 71 & 36.7162 & & - & - & - & 3-ethylpentane \\
\hline 39 & B9B & 395 & 38.2697 & & - & - & - & - \\
\hline 40 & $\mathrm{~B} 6 \mathrm{C}$ & 71 & 38.8875 & & - & - & - & 3-ethylhexane \\
\hline 41 & B6B & 71 & 39.0147 & & - & - & - & - \\
\hline 42 & $\mathrm{~B} 4 \mathrm{C}$ & 57 & 39.4792 & & - & - & - & 3-ethylhexane \\
\hline 43 & B6B & 57 & 39.4822 & & - & - & - & $\begin{array}{l}\text { 3,3-dimethyl-1- } \\
\text { butene }\end{array}$ \\
\hline 44 & $\mathrm{~B} 4 \mathrm{C}$ & 71 & 39.6266 & & - & - & - & 3-ethylpentane \\
\hline 45 & $\mathrm{~B} 3 \mathrm{C}$ & 71 & 39.7884 & & - & - & - & - \\
\hline 46 & B6B & 57 & 40.4997 & & - & - & $\begin{array}{l}\text { 3-hexanone, } \\
\text { 2,2-dimethyl- }\end{array}$ & 2-methylbutane \\
\hline 47 & $\mathrm{~B} 6 \mathrm{C}$ & 57 & 40.7684 & & - & - & - & 3-ethylpentane \\
\hline 48 & $\mathrm{~B} 3 \mathrm{C}$ & 71 & 40.7722 & & - & - & - & - \\
\hline 49 & $\mathrm{~B} 4 \mathrm{C}$ & 57 & 43.09 & & - & - & - & 3-ethylpentane \\
\hline 50 & B6B & 57 & 43.0982 & & - & - & - & $\begin{array}{l}2,2,4,6,6- \\
\text { pentamethylheptane }\end{array}$ \\
\hline 51 & $\mathrm{~B} 6 \mathrm{C}$ & 85 & 43.2865 & & - & - & - & 2-methylnonane \\
\hline 52 & B6B & 71 & 43.3628 & & - & - & - & 3-ethylpentane \\
\hline 53 & $\mathrm{~B} 3 \mathrm{C}$ & 71 & 43.3691 & & - & - & - & - \\
\hline 54 & $\mathrm{~B} 3 \mathrm{~B}$ & 85 & 43.7727 & & - & - & - & $\begin{array}{l}\text { 3,3-dimethyl-1- } \\
\text { butene }\end{array}$ \\
\hline 55 & B4B & 85 & 44.3901 & & - & - & - & Amitrole \\
\hline 56 & B6B & 71 & 44.3953 & & - & - & - & 3-aminopropiononitrile \\
\hline 57 & $\mathrm{~B} 4 \mathrm{~A}$ & 71 & 46.2638 & & - & - & - & - \\
\hline 58 & $\mathrm{~B} 3 \mathrm{C}$ & 71 & 46.8143 & & - & - & - & 2,3-dimethylbutane \\
\hline 59 & B6B & 71 & 46.822 & & - & - & $\begin{array}{l}\text { 3-hexanone, } \\
\text { 2,2-dimethyl- }\end{array}$ & - \\
\hline 60 & $\mathrm{~B} 6 \mathrm{C}$ & 71 & 47.3544 & & - & - & - & - \\
\hline 61 & $\mathrm{~B} 4 \mathrm{~A}$ & 71 & 47.7467 & & - & - & - & 3-ethylypentane \\
\hline 62 & $\mathrm{~B} 3 \mathrm{~A}$ & 57 & 47.7529 & & - & - & - & $\begin{array}{l}\text { 3,3-dimethyl-1- } \\
\text { butene }\end{array}$ \\
\hline 63 & $\mathrm{~B} 4 \mathrm{~A}$ & 71 & 48.0072 & & - & - & - & - \\
\hline 64 & B6B & 71 & 48.0159 & & - & - & - & - \\
\hline
\end{tabular}


Table S3. Cont.

\begin{tabular}{llllllll}
\hline 65 & B6C & 71 & 48.0169 & - & - & - & - \\
66 & B4A & 71 & 48.0321 & - & - & - & - \\
67 & B4B & 71 & 50.7731 & - & - & - & - \\
\hline
\end{tabular}

Table S4. Compound peaks detected from GC-MS analysis of samples used for evaluation of temporal and spatial patterns of non-polar metabolites of three cryptic species of $P$. hornemanni found in the Visayas. Identifications based on comparison of either Kovat's Indices (KI) of compounds retrieved from the Retention Index Calculator [37] or mass spectral comparison of compounds retrieved from NIST or MassBase. Asterisk (*) indicates compounds with parent ions showing halogenated mass spectral patterns.

\begin{tabular}{|c|c|c|c|c|c|c|c|}
\hline \multirow[t]{2}{*}{ \# } & \multirow[t]{2}{*}{ Sample } & \multirow[t]{2}{*}{$\begin{array}{l}\text { Base } \\
\text { Peak }\end{array}$} & \multirow[b]{2}{*}{ RT } & \multirow[t]{2}{*}{ KI } & \multicolumn{2}{|l|}{ KI Based ID } & \multirow{2}{*}{$\begin{array}{l}\text { Mass Spectra Based ID } \\
\text { Massbase }\end{array}$} \\
\hline & & & & & Nearest KI & Lucero et al. [37] & \\
\hline 1 & $3 \mathrm{~A}$ & 57 & 8.1118 & 1065 & 1062 & y-terpinene & undecane \\
\hline 2 & $15 \mathrm{~A}$ & 57 & 14.556 & 1285 & 1286 & borneol acetate & 1-nonene \\
\hline 3 & $9 \mathrm{~A}$ & 57 & 14.556 & 1285 & 1286 & borneol acetate & pentacosane \\
\hline 4 & $29 \mathrm{~A}$ & 57 & 20.3128 & 1500 & 1499 & a-muurolene & tricosane \\
\hline 5 & $15 \mathrm{~B}$ & 71 & 20.5458 & 1510 & 1509 & $\beta$-bisabolene & 3-ethylpentane \\
\hline 6 & $15 \mathrm{~A}$ & 57 & 25.186 & 1705 & 1686 & 8-cedren-13-ol & - \\
\hline 7 & $34 \mathrm{~A}$ & 57 & 25.4206 & 1716 & 1735 & oplopanone & - \\
\hline 8 & $15 \mathrm{~B}$ & 71 & 26.6674 & 1772 & 1761 & benzyl-benzoate & 2-methylbutane \\
\hline 9 & $15 \mathrm{~A}$ & 57 & 27.8534 & 1827 & 1827 & isopropyl tetradecanoate & \\
\hline 10 & 44BB & 71 & 30.0015 & 1930 & 1927 & methyl hexadecanoate & docosane \\
\hline 11 & $8 \mathrm{~B}$ & 57 & 30.4069 & 1950 & 1927 & methyl hexadecanoate & \\
\hline 12 & $15 \mathrm{~B}$ & 71 & 31.6111 & - & - & - & - \\
\hline 13 & $15 \mathrm{~A}$ & 57 & 31.8326 & - & - & - & - \\
\hline 14 & $15 \mathrm{~B}$ & 57 & 31.8342 & - & - & - & 1,4-dimethylhexane \\
\hline 15 & $44 \mathrm{BA}$ & 71 & 34.1535 & - & - & - & docosane \\
\hline 16 & $15 \mathrm{~B}$ & 71 & 34.2967 & - & - & - & 3-ethylpentane \\
\hline 17 & $15 \mathrm{~A}$ & 57 & 34.76 & - & - & - & 1-octene \\
\hline 18 & $15 \mathrm{~A}$ & 71 & 35.4496 & - & - & - & 2-methylbutane \\
\hline 19 & $15 \mathrm{~B}$ & 57 & 35.5757 & - & - & - & - \\
\hline 20 & $15 \mathrm{~B}$ & 57 & 35.5757 & - & - & - & 2,2-dimethylbutane \\
\hline 21 & $44 \mathrm{BA}$ & 71 & 37.9407 & - & - & - & docosane \\
\hline 22 & $15 \mathrm{~B}$ & 410 & 38.2743 & - & - & - & - \\
\hline 23 & $15 \mathrm{~A}$ & 71 & 39.3484 & - & - & - & 3-ethylhexane \\
\hline 24 & $15 \mathrm{~A}$ & 71 & 40.0877 & - & - & - & 2,2-dimethylbutane \\
\hline 25 & $15 \mathrm{~A}$ & 71 & 40.0981 & - & - & - & beta-Aminopropionitrile \\
\hline 26 & $15 \mathrm{~B}$ & 71 & 42.5358 & - & - & - & 2-methylbutane \\
\hline 27 & $15 \mathrm{~B}$ & 57 & 43.9626 & - & - & - & 4-methyloctane \\
\hline 28 & $44 \mathrm{C}$ & 71 & 44.6454 & - & - & - & - \\
\hline 29 & $15 \mathrm{~A}$ & 57 & 45.2255 & - & - & - & 2,2-dimethylbutane \\
\hline 30 & $15 \mathrm{~A}$ & 71 & 47.3529 & - & - & - & - \\
\hline
\end{tabular}


Table S4. Cont.

\begin{tabular}{llllllll}
\hline 31 & $15 \mathrm{~B}$ & 57 & 47.3534 & - & - & - & - \\
32 & $15 \mathrm{~B}$ & 57 & 47.3581 & - & - & - & 2,4-dimethylpentane \\
33 & $15 \mathrm{~A}$ & 71 & 47.6237 & - & - & - & 2,4-dimethylhexane \\
\hline
\end{tabular}

Figure S1. Map of sampling sites. (a) Map of the Philippines indicating location of Batanes and Visayas; (b) Sampling sites in Batan and Sabtang Islands in Batanes; (c) Sampling sites in Siquijor, Negros, and Cebu Islands in the Visayas).

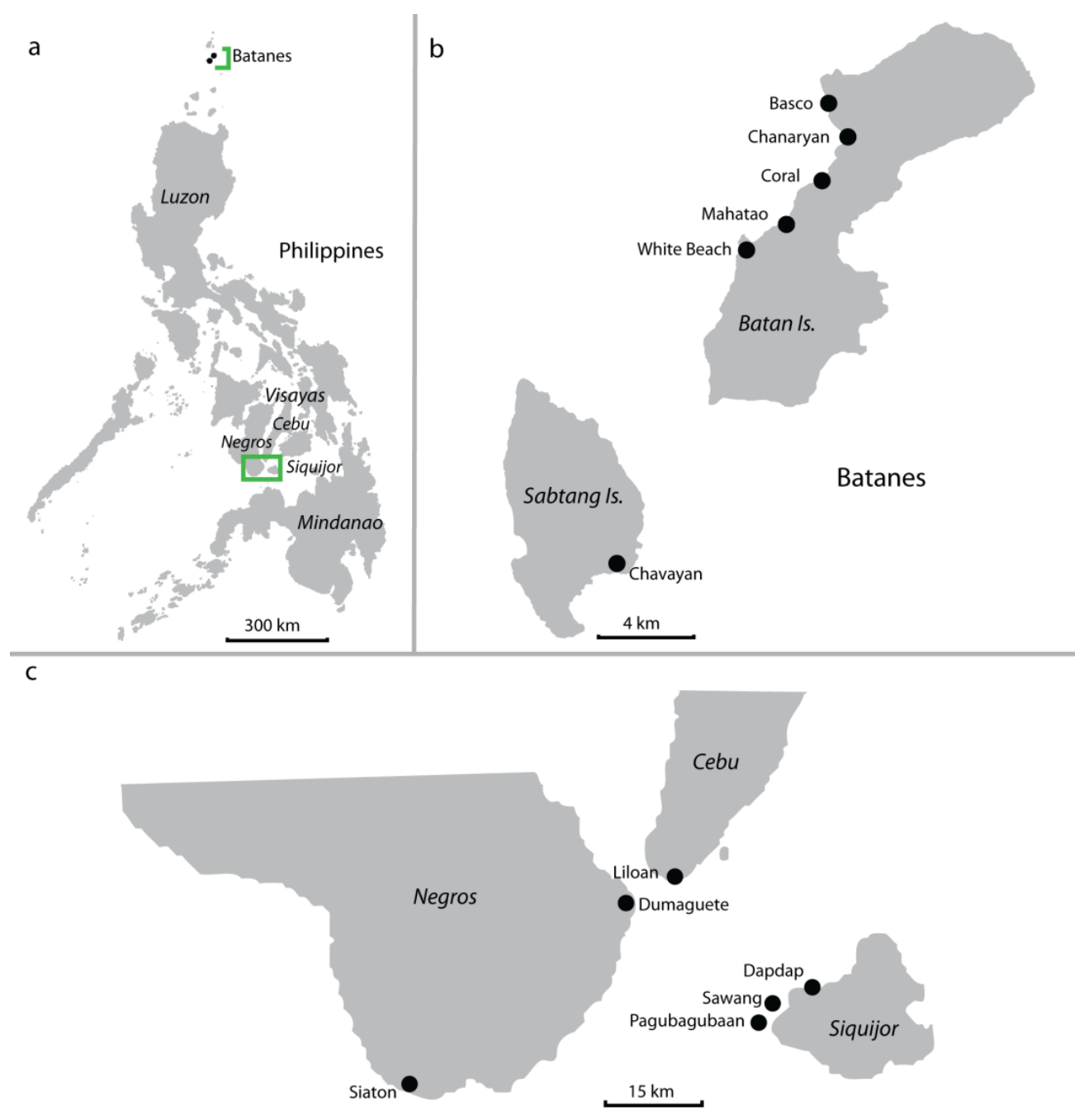

\section{References}

1. Williams, D.H.; Stone, M.J.; Hauck, P.R.; Rahman, S.K. Why are secondary metabolites (natural products) biosynthesized? J. Nat. Prod. 1989, 52, 1189-1208.

2. Hay, M.E.; Fenical, W. Chemical ecology and marine biodiversity: Insights and products from the sea. Oceanography 1996, 9, 10-20.

3. Wise, M.L. Monoterpene biosynthesis in marine algae. Phycologia 2003, 42, 370-377.

4. Bhat, S.V.; Nagasampagi, B.A.; Sivakumar, M. Chemistry of Natural Products; Narosa Publishing House: New Delhi, India, 2005. 
5. Bourgaud, F.; Gravot, A.; Milesi, S.; Gontier, E. Production of plant secondary metabolites: A historical perspective. Plant Sci. 2001, 161, 839-851.

6. Gribble, G.W. The diversity of naturally produced organohalogens. Chemosphere 2003, 52, 289-297.

7. Dworjanyn, S.A.; de Nys, R.; Steinberg, P.D. Localisation and surface quantification of secondary metabolites in the red alga Delisea pulchra. Mar. Biol. 1999, 133, 727-736.

8. Gunatilaka, A.A.L.; Paul, V.J.; Park, P.U.; Puglisi, M.P.; Gitler, A.D.; Eggleston, D.S.; Haltiwanger, R.C.; Kingston, D.G.I. Apakaochtodenes a and b: Two tetrahalogenated monoterpenes from the red marine alga Portieria hornemannii. J. Nat. Prod. 1999, 62, 1376-1378.

9. Kladi, M.; Vagias, C.; Roussis, V. Volatile halogenated metabolites from marine red algae. Phytochem. Rev. 2004, 3, 337-366.

10. Fenical, W. Halogenation in the Rhodophyta: A review. J. Phycol 1975, 11, 245-259.

11. Barahona, L.F.; Rorrer, G.L. Isolation of halogenated monoterpenes from bioreactor-cultured microplantlets of the macrophytic red algae Ochtodes secundiramea and Portieria hornemannii. J. Nat. Prod. 2003, 66, 743-751.

12. Andrianasolo, E.H.; France, D.; Cornell-Kennon, S.; Gerwick, W.H. DNA methyl transferase inhibiting halogenated monoterpenes from the Madagascar red marine alga Portieria hornemannii. J. Nat. Prod. 2006, 69, 576-579.

13. Kuniyoshi, M.; Oshiro, N.; Miono, T.; Higa, T. Halogenated monoterpenes having a cyclohexadienone from the red alga Portieria hornemanni. J. Chin. Chem. Soc. 2003, 50, 167-170.

14. Smit, A.J. Medicinal and pharmaceutical uses of seaweed natural products: A review. J. Appl. Phycol. 2004, 16, 245-262.

15. Kamenarska, Z.; Ivanova, A.; Stancheva, R.; Stoyneva, M.; Stefanov, K.; Dimitrova-Konaklieva, S.; Popov, S. Volatile compounds from some Black Sea red algae and their chemotaxonomic application. Bot. Mar. 2006, 49, 47-56.

16. Blunt, J.W.; Copp, B.R.; Hu, W.P.; Munro, M.H.G.; Northcote, P.T.; Prinsep, M.R. Marine natural products. Nat. Prod. Rep. 2007, 24, 31-86.

17. Bhadury, P.; Wright, P.C. Exploitation of marine algae: Biogenic compounds for potential antifouling applications. Planta 2004, 219, 561-578.

18. Ichikawa, N.; Naya, Y.; Enomoto, S. New halogenated monoterpenes from Desmia (Chondrococcus) hornemanni. Chem. Lett. 1974, 3, 1333-1336.

19. Burreson, B.J.; Woolard, F.X.; Moore, R.E. Chondrocole a and b, two halogenated dimethylhexahydrobenzofurans from the red alga Chondrococcus hornemannii (Mertens) Schmitz. Tetrahedron Lett. 1975, 16, 2155-2158.

20. Coll, J.C.; Wright, A.D. Tropical marine algae.1. New halogenated monoterpenes from Chondrococcus hornemannii (Rhodophyta, Gigartinales, Rhizophyllidaceae). Aust. J. Chem. 1987, 40, 1893-1900.

21. Wright, A.D.; Konig, G.M.; Sticher, O.; de Nys, R. Five new monoterpenes from the marine red alga Portieria hornemannii. Tetrahedron 1991, 47, 5717-5724. 
22. Fuller, R.W.; Cardellina, J.H.; Kato, Y.; Brinen, L.S.; Clardy, J.; Snader, K.M.; Boyd, M.R. A pentahalogenated monoterpene from the red alga Portieria hornemannii produces a novel cytotoxicity profile against a diverse panel of human tumor cell lines. J. Med. Chem. 1992, 35, 3007-3011.

23. Fuller, R.W.; Cardellina, J.H.; Jurek, J.; Scheuer, P.J.; Alvaradolindner, B.; McGuire, M.; Gray, G.N.; Steiner, J.R.; Clardy, J.; Menez, E.; et al. Isolation and structure activity features of halomon-related antitumor monoterpenes from the red alga Portieria hornemannii. J. Med. Chem. 1994, 37, 4407-4411.

24. Matlock, D.B.; Ginsburg, D.W.; Paul, V.J. Spatial variability in secondary metabolite production by the tropical red alga Portieria hornemannii. Hydrobiologia 1999, 399, 267-273.

25. Puglisi, M.P.; Paul, V.J. Intraspecific variation in the red alga Portieria hornemannii: Monoterpene concentrations are not influenced by nitrogen or phosphorus enrichment. Mar. Biol. 1997, 128, 161-170.

26. Miller, K.; Alvarez, B.; Battershill, C.; Northcote, P.; Parthasarathy, H. Genetic, morphological, and chemical divergence in the sponge genus Latrunculia (Porifera: Demospongiae) from New Zealand. Mar. Biol. 2001, 139, 235-250.

27. Pietra, F. Biodiversity and Natural Product Diversity; Pergamon: Trento, Italy, 2002; Volume 21, p. 351.

28. McGovern, T.M.; Hellberg, M.E. Cryptic species, cryptic endosymbionts, and geographical variation in chemical defences in the bryozoan Bugula neritina. Mol. Ecol. 2003, 12, 1207-1215.

29. Payo, D.A. Diversity of the Marine Red Alga Portieria in the Philippines, an Integrative Approach. Ph.D. Thesis, Ghent University, Gent, Belgium, 2011.

30. Fiehn, O.; Kind, T. Metabolite Profiling in Blood Plasma. In Methods in Molecular Biology, Metabolomics: Methods and Protocols; Weckwerth, W., Ed.; Humana Press: Totowa, NJ, USA, 2006; Volume 358, pp. 3-17.

31. Fiehn, O. Metabolomics-The link between genotypes and phenotypes. Plant Mol. Biol. 2002, 48, 155-171.

32. Lucero, M.; Estell, R.; Tellez, M.; Frederickson, E. A retention index calculator simplifies identification of plant volatile organic compounds. Phytochem. Anal. 2009, 20, 378-384.

33. Egorin, M.J.; Rosen, D.M.; Benjamin, S.E.; Callery, P.S.; Sentz, D.L.; Eiseman, J.L. In vitro metabolism by mouse and human liver preparations of halomon, an antitumor halogenated monoterpene. Cancer Chemother. Pharmacol. 1997, 41, 9-14.

34. Pelletreau, K.N.; Targett, N.M. New perspectives for addressing patterns of secondary metabolites in marine macroalgae. Algal Chem. Ecol. 2008, 121-146.

35. Wise, M.L.; Rorrer, G.L.; Polzin, J.J.; Croteau, R. Biosynthesis of marine natural products: Isolation and characterization of a myrcene synthase from cultured tissues of the marine red alga Ochtodes secundiramea. Arch. Biochem. Biophys. 2002, 400, 125-132.

36. Thornber, C.; Stachowicz, J.J.; Gaines, S. Tissue type matters: Selective herbivory on different life history stages of an isomorphic alga. Ecology 2006, 87, 2255-2263.

37. Verges, A.; Paul, N.A.; Steinberg, P.D. Sex and life-history stage alter herbivore responses to a chemically defended red alga. Ecology 2008, 89, 1334-1343. 
38. Cavalcanti, D.N.; de Oliveira, M.A.R.; De-Paula, J.C.; Barbosa, L.S.; Fogel, T.; Pinto, M.A.; de Palmer Paixão, I.C.N.; Teixeira, V.L. Variability of a diterpene with potential anti-HIV activity isolated from the Brazilian brown alga Dictyota menstrualis. J. Appl. Phycol. 2010, 5, 1-4.

39. Huelsenbeck, J.P.; Ronquist, F. Mrbayes: Bayesian inference of phylogenetic trees. Bioinformatics 2001, 17, 754-755.

40. Posada, D. Jmodeltest: Phylogenetic model averaging. Mol. Biol. Evol. 2008, 25, 1253-1256.

41. Rambaut, A.; Drummond, A.J. Tracer v1.4. Available online: http://beast.bio.ed.ac.uk/Tracer (accessed on 11 October 2007).

42. AMDIS. Available online: http://www.amdis.net (accessed on 7 March 2010).

43. Styczynski, M.P.; Moxley, J.F.; Tong, L.V.; Walther, J.L.; Jensen, K.L.; Stephanopoulos, G.N. Systematic identification of conserved metabolites in GC/MS data for metabolomics and biomarker discovery. Anal. Chem. 2007, 79, 966-973. Available online: http://spectconnect.mit.edu (accessed on 23 February 2010).

44. Horai, H.; Arita, M.; Kanaya, S.; Nihei, Y.; Ikeda, T.; Suwa, K.; Ojima, Y.; Tanaka, K.; Tanaka, S.; Aoshima, K.; et al. Massbank: A public repository for sharing mass spectral data for life sciences. J. Mass Spectrometry 2010, 45, 703-714. Available online: http://www.massbank.jp (accessed on 18 March 2010).

45. The Pherobase: Database of Pheromones and Semiochemicals. Available online: http://www.pherobase.com (accessed on 11 August 2010).

46. Burreson, B.J.; Woolard, F.X.; Moore, R.E. Evidence for the biogenesis of halogenated myrcenes from the red alga Chondrococcus hornemanni. Chem. Lett. 1975, 4, 1111-1114.

47. Ichikawa, N.; Naya, Y.; Enomoto, S. Halogenated monoterpene derivatives from Desmia (Chondrococcus) japonicus. Proc. Jpn. Acad. 1975, 51, 562-565.

48. Woolard, F.X.; Moore, R.E.; Mahendran, M.; Sivapalan, A. (-)-3-bromomethyl-3-chloro-7methyl-1, 6-octadiene from Sri Lankan Chondrococcus hornemanni. Phytochemistry 1976, 15, 1069-1070.

49. Higa, T. 2-(1-chloro-2-hydroxyethyl)-4,4-dimethylcyclohexa-2,5-dienone: A precursor of 4, 5-dimethylbenzo [ $\beta$ ] furan from the red alga Desmia hornemanni. Tetrahedron Lett. 1985, 26, 2335-2336.

50. Coll, J.C.; Wright, A.D. Tropical marine-algae. 6. New monoterpenes from several collections of Chondrococcus hornemannii (Rhodophyta, Gigartinales, Rhizophyllidaceae). Aust. J. Chem. 1989, 42, 1983-1993.

(C) 2011 by the authors; licensee MDPI, Basel, Switzerland. This article is an open access article distributed under the terms and conditions of the Creative Commons Attribution license (http://creativecommons.org/licenses/by/3.0/). 